\title{
الفنون التشكيليةه(')
}

\begin{tabular}{|c|}
\hline فخرية بنت خلفان اليحيائي \\
\hline استاذ مشارك \\
\hline قسم التربية القنية ـ كلية التربية \\
\hline جامعة السلطان قابوس - سلطنة عمان \\
\hline
\end{tabular}

\begin{tabular}{|c|}
\hline سلمان الحجري \\
\hline أستاذ مساعد \\
\hline قسم التربية الفنية ـ كلية التربية \\
\hline جامعة السلطان قابوس - سلطنة عمان \\
\hline salmanh@squ.edu.om \\
\hline 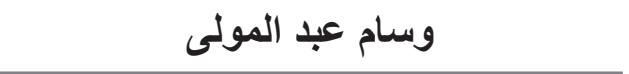 \\
\hline أستاذ مساعد \\
\hline قسم التربية الفنية ـ كلية التربية \\
\hline جامعة السلطان قابوس - سلطنة عمان \\
\hline wissem@squ.edu.om \\
\hline
\end{tabular}

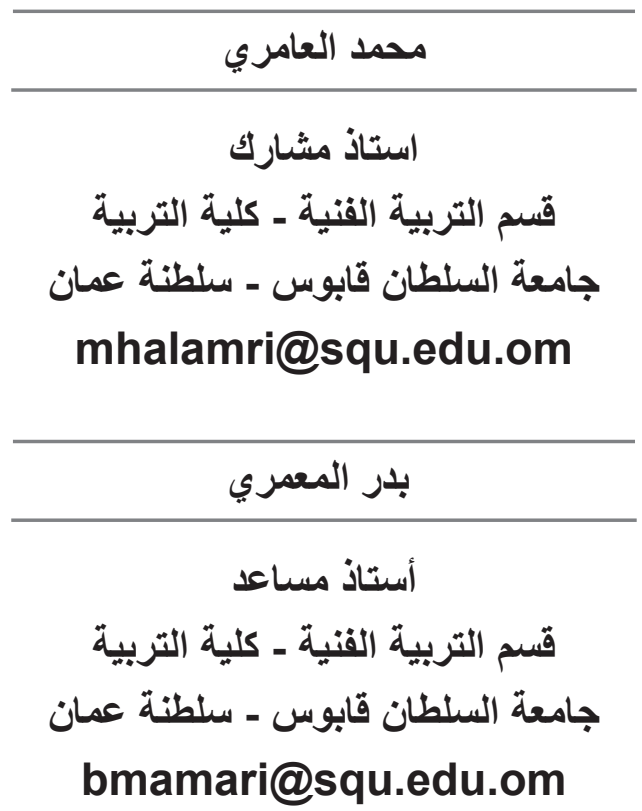

$$
\begin{aligned}
& \text { تاريخ الاستلام : 10/.0/11 ب/rq }
\end{aligned}
$$

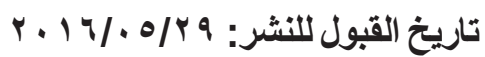




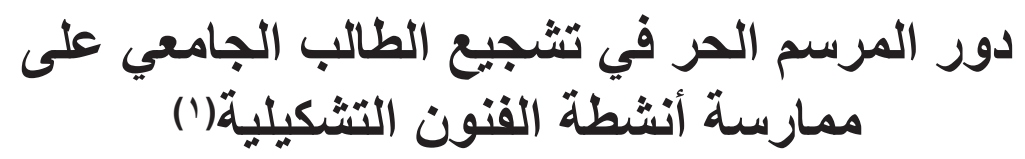

فخرية بنت خلفان اليحيائي، محمد العامري، سلمان الحجري، بلر المعمري، وسام عبد المولى

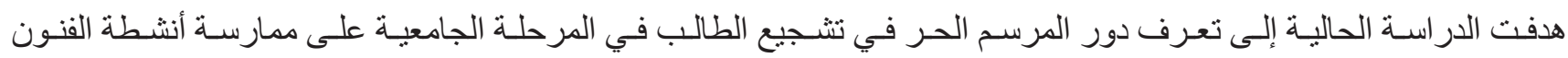

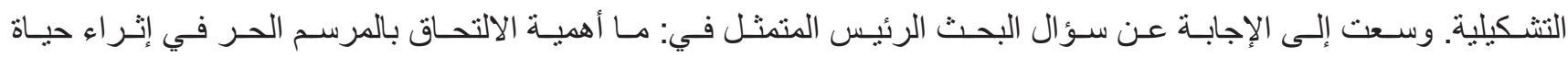

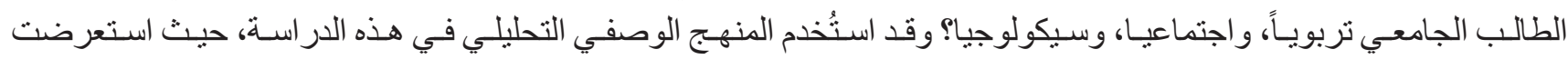

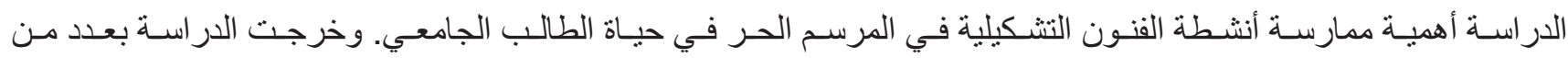

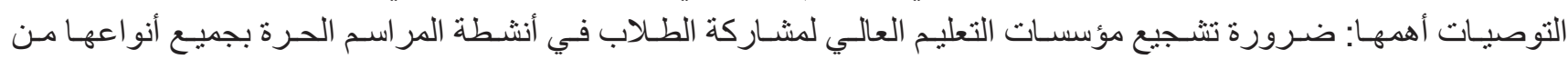

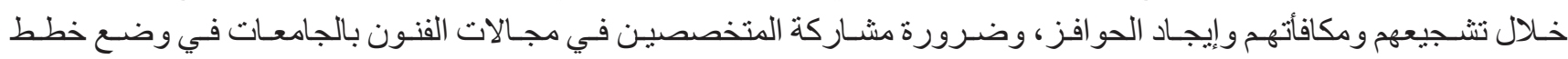

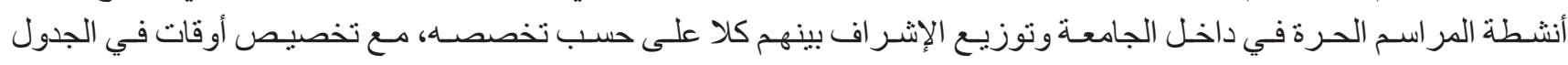

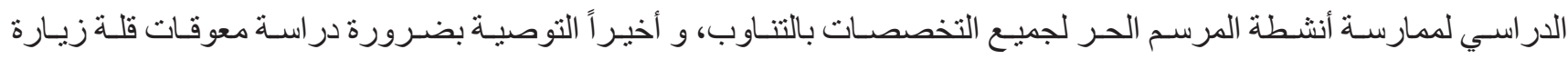

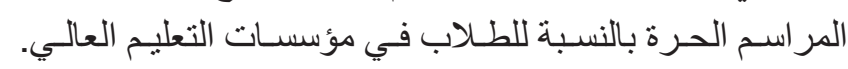
كلمات مفتاحية: المرسم الحر، أنشطة الفنون التشكيلية، التعليم العالي.

\title{
The Role of Open Art Studio in Encouraging University Students to Practice Art Activities
}

Fakhriya Al-Yahyai, Mohammed Al-Amri, Salman Alhajr, Badar Al-mamari, Wissem Abdelmoula

\begin{abstract}
The current study aims to explore the role of the Open Art Studio in encouraging university students to practice arts. It seeks to answer the following main research questions: What is the role of the Open Art Studio in enhancing university-students' life in terms of educational, sociological and physiological aspects?

The findings of the study show the importance of practicing art activities in the Open Art Studio in enhancing university-students' life as well as analyzing the integrating role of the educational, physiological and sociological of practicing art in the Open Art Studio. This study ended with some important recommendations such as the importance of higher educational institutions in encouraging students' participation in practicing all types of arts activities and supporting them and offering incentives, the necessity of art specialists participating at universities in planning policy of outside classrooms activities and supervising these activities according to their specializations, and allocating some time in the study timetable for practicing extracurricular activities in all university disciplines. Finally, it recommends the need to further study the difficulties behind the university students' limited number of visits to Open Art Studios.
\end{abstract}

Keywords: Open Art Studio, Art Activities, Higher Education. 


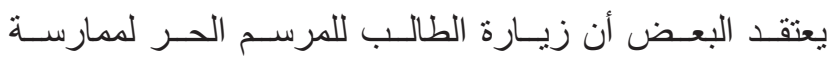

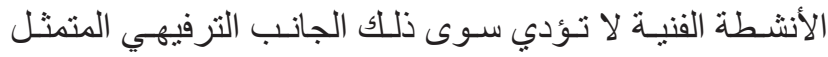

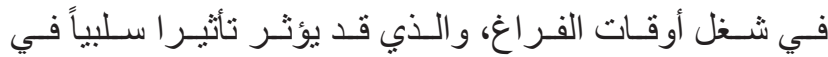

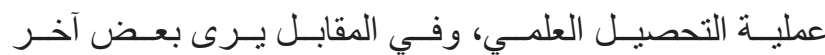

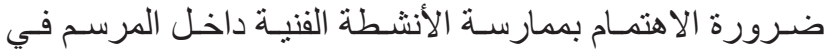
جميع المر احل التعليميـة حتى على مسـتوى المرحلـة الجامعية؛

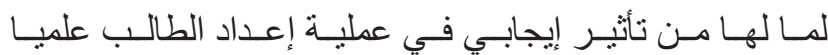

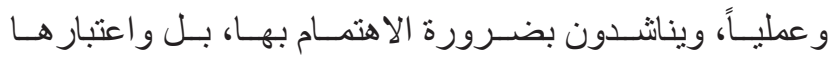

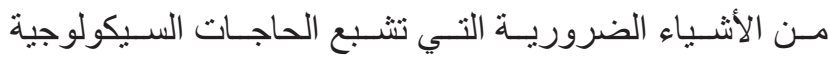

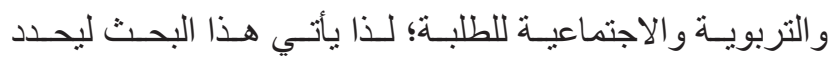

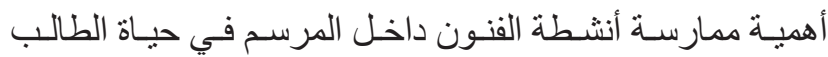
الجامعسي مـن الناحيـة السـيكولوجية، و التربويــة و الاجتماعيـة.

\section{أهداف الاراسـة}

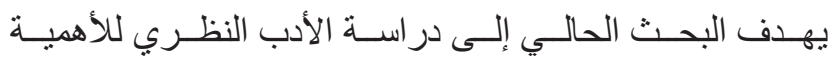

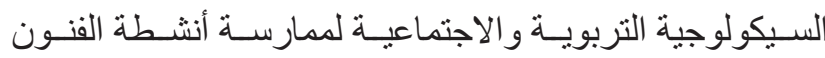

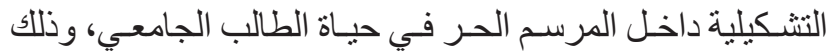

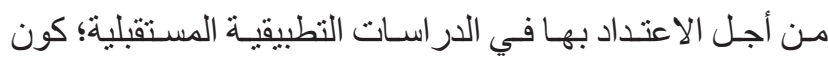
أن هذا البحث هـ جـز هـ مـن مشـروع بحثي مدول.

\section{منهجية الدراسـة}

يتبـع البحث المنهج التحليلي الوصفي في إظهار الدور التربوي و الاجتماعي و السيكولوجي للفنون التشـكيلية داخل المرسم الحر في إثر اء حيـاة الطالب الجامعي في مؤسســات التعليم العالي.

\section{مصطلحات الار اسة}

المرسـم الحـر : هــو المـكان المخصـص لممارســة جميـع

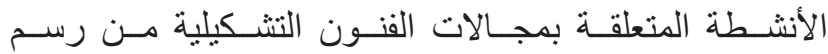

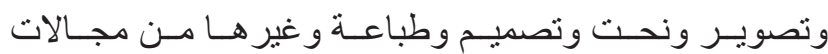

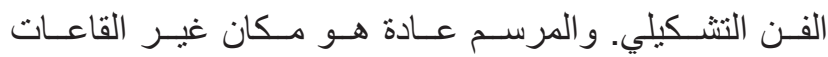

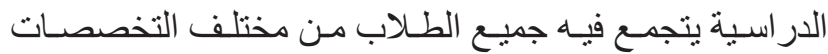

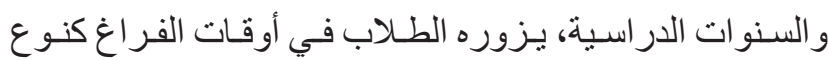

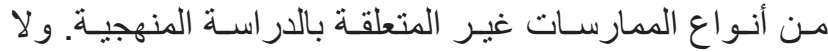

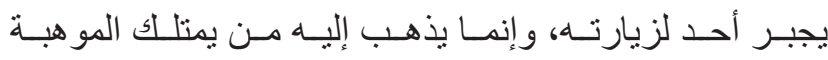

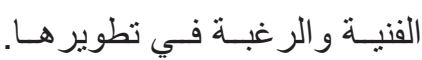

\section{الإطار النظري للاراسـة}

يعتبر جودي (99V ( I ) الفنـون القوى المهذبـة لغر ائز الإنسـان،

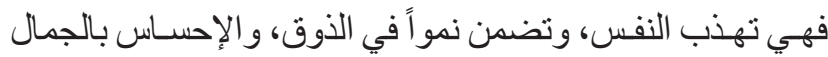

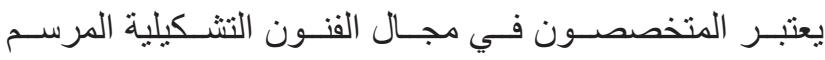

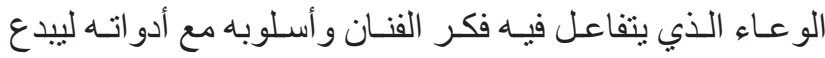

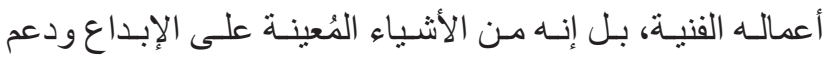

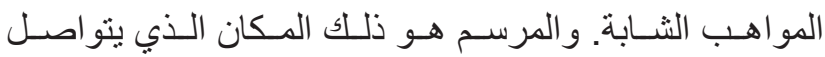

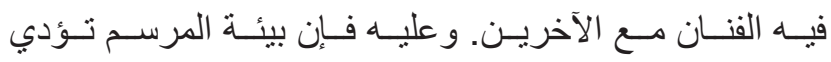

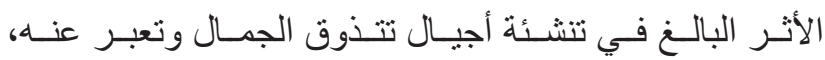
وفي ذات الوقت تحترم الآخريـن في تعبير اتهـ و انفعالاتهـ.

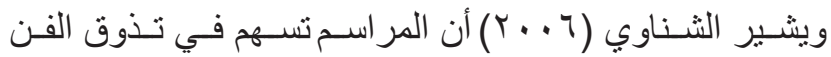

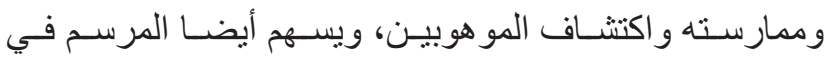

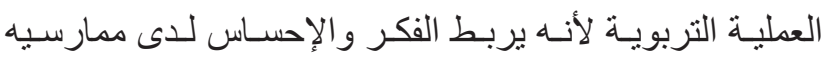

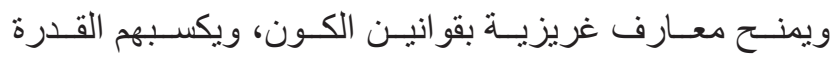
على التو افق مـع الطبيعـة. إلا أن زيـارة المرسـم ارتبطت بمفاهيم التسـرب و الغياب و التأثير

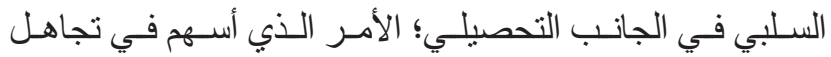

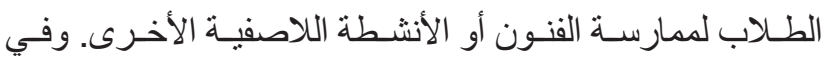

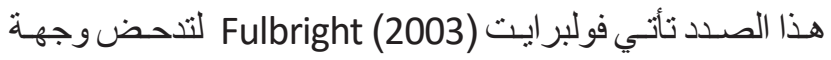

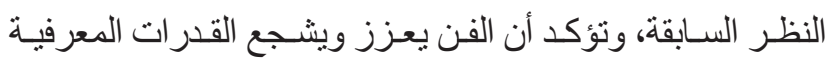

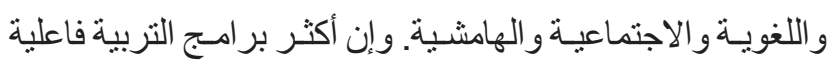

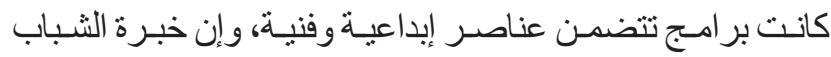

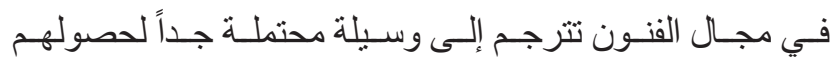

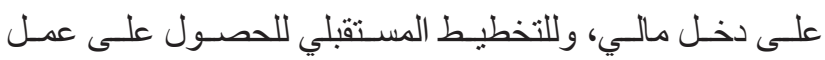

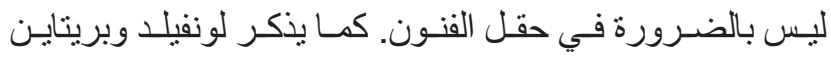

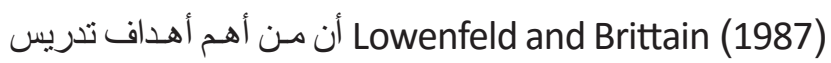

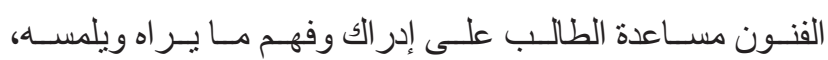

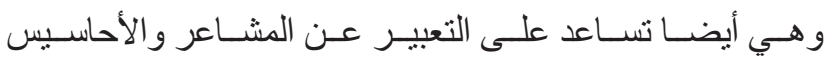

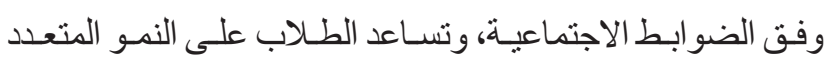

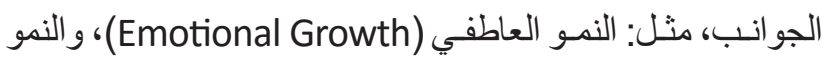
الفكـري (Intellectual Growth) و النمــو البدنـي (Physical) و والنمـو الإدر اكي (Perceptual Growth) و والنمـو (Pochth) الاجتماعـي (Social Growth) و النمـو الجمالـي (Aesthetic) Growth) وتأتي الدراسـة الحاليـة لتركز على عمليـة بحـث أهمية المرسـم

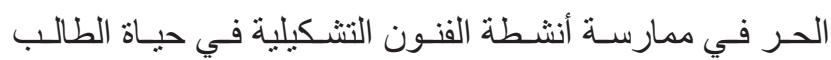

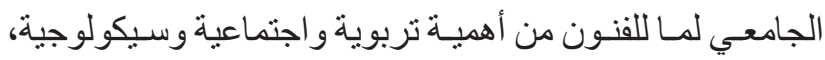

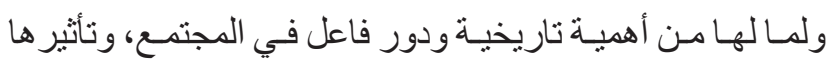

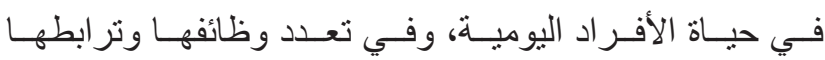
العضـوي باعتبار هـا وسـائل عمليـة تقوم على إنشباع الحاجـات

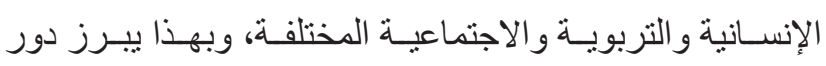
الفن في تطوير المعرفـة الإنسـانية وتر اكمها. 
المعلومـات و الحقائتق و المفاهيـم العلميـة و الفنبـة المرتبطة بفلسـفة الفـن التشـكيلي، وتتمسي المـدركات الحسية من خلال الممارسـات

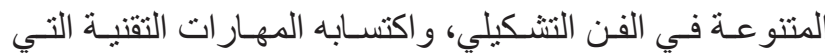
تعينــه علـى التحكـم فـي اسـتخدام الخامــات البيئيـة و أســاليب وطرق تشـكيلها وتجهيز هـا، و الربـط بينهـا وبيـن التطـور العلمي

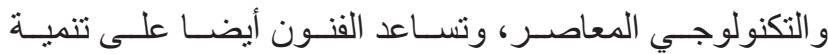
الجو انـب الوجدانيـة مـن خـلال تتميـة الاتجاهـات الإيجابيـة للقيـم الاجتماعيـة، و القدرة على رؤيسة وتـوق الأعمـال الفنيـة وتـذوق

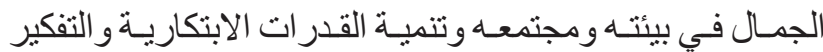

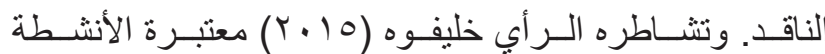

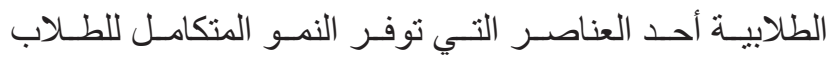

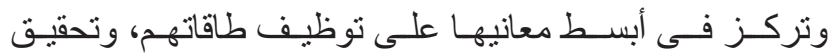
ميولهم وذو اتهـم، ونتـعر هم بكيانهـم الاجتماعي.

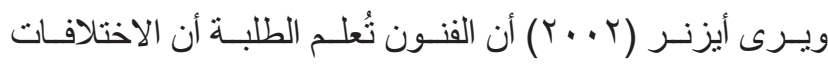

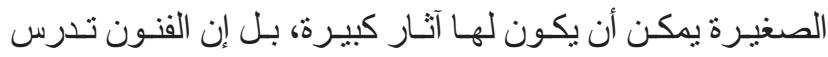
الطلبـة كيـف يفكرون مسن خـلال المـواد و الخامـات واسـتخدامها؛ فجميع أثـكال الفنـون توظف بعض المعانـي مـن خلال الأشـكال

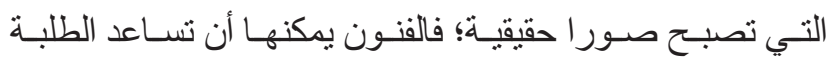

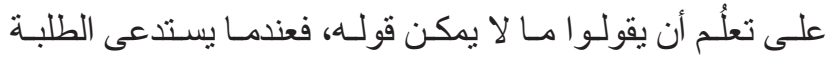

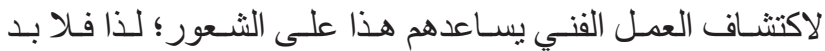

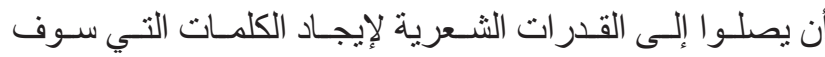
تسـاعدهم على القيـام بهـذه المهمهـة. فالفــون تمكنتـا مـن امتـلاكك

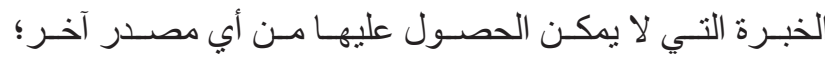

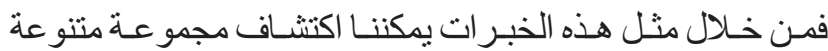
وو اسـعة مـن الأشـياء التـي نحسن قـادرون على الثـعور بهـا.

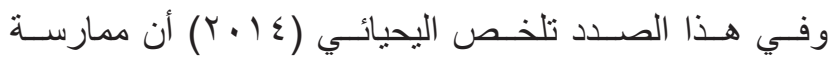
الفنـون تنمـي الجو انـب العاطفيـة و الفكريـة و البدنيـة و الإدر اكيـة

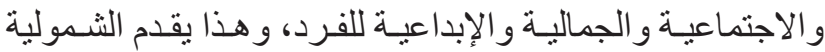

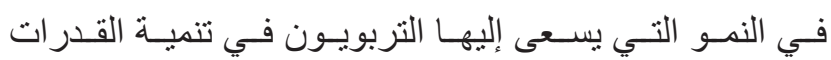

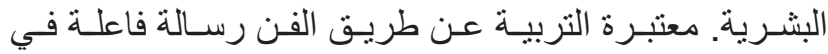
تتميـة مـوارد المجتمـع علىى المسـتوى البثـري أو الإنتاجـي؛

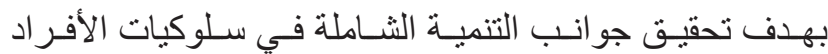
و إرهـاف الحس الجمالـي، و التذوق الفنـي، إضـافـة إلـى تتمبـة

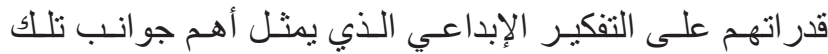
التنميـة و اسـتثمار تلـلك القـدرات في خدمـة المجتمـع.

المحسور الأول: الأهميـة السيكولوجية لممارسـة أنشطة الفنون

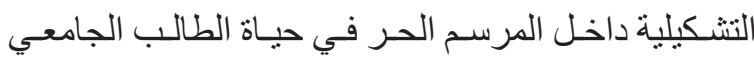

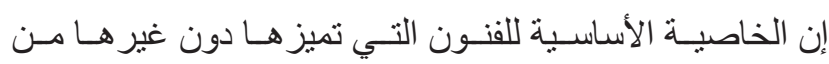

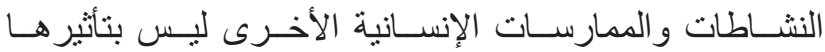

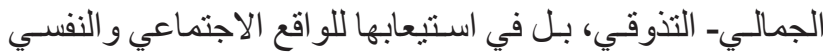

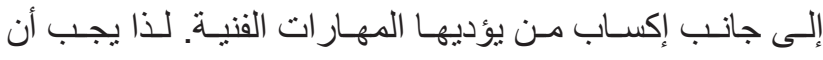

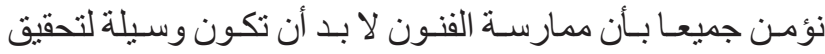

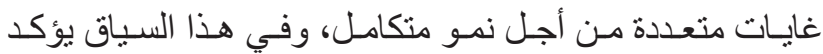

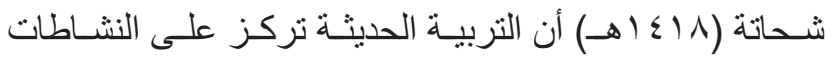

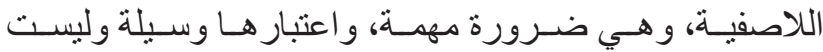

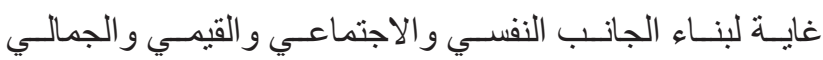

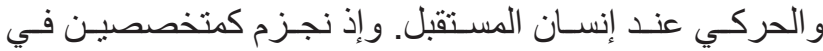

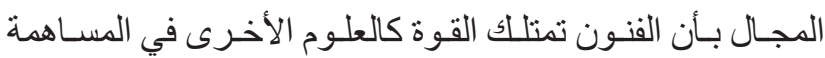

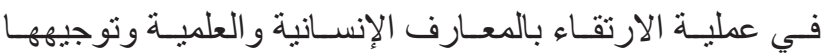

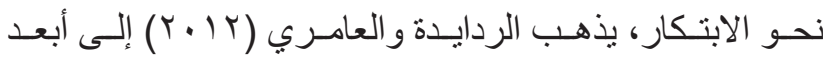

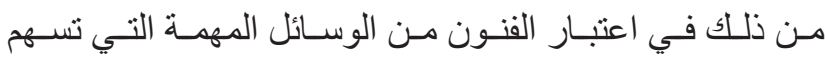
في تنشيط عمليـة التفاعل بيـن الحدس و الحـو اس معـاً، وتمثنل

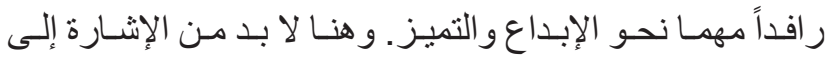

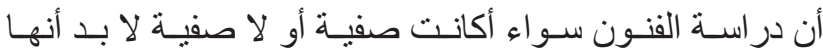

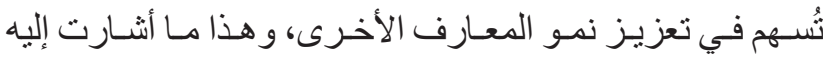

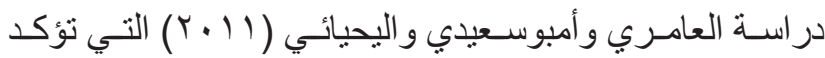
أهميـة التكامـل المعرفي بيـن الفنـون و العلوم، الذـي بـدوره يؤثر بطريقـة إيجابيـة في الجو انب الأكاديميـة والاجتماعية و النفسية،

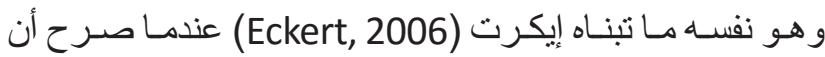

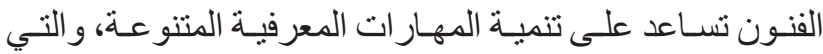
بدور هـا تسـاعد على الكثف عن المشكلات المعقدة المرتبطـة

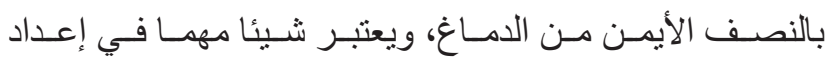
الأفر اد للعالـم الحقيقي.

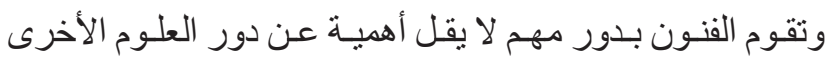
في هذا الجانب. ويدعم هذا التوجه ببـاوي (9 . . ب) الذي يشـير

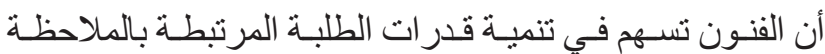
و الإدر الك و التمييز بيـن المثير ات الحسية و اللمسية و البصريــة.

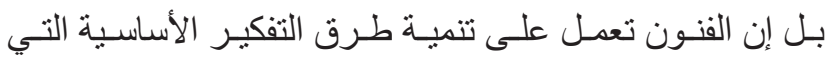

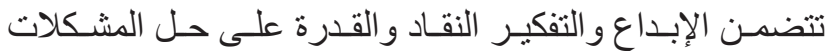

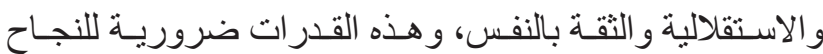

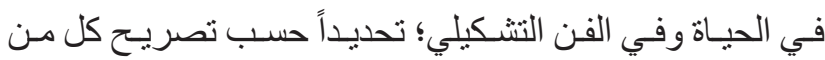

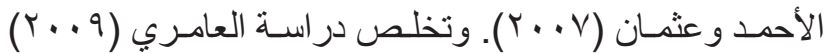

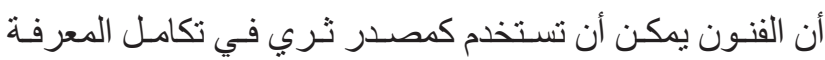

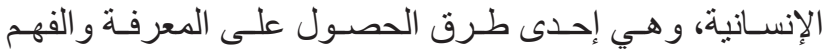

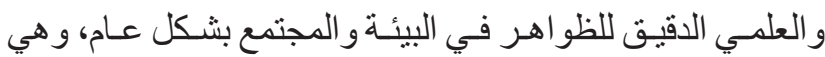

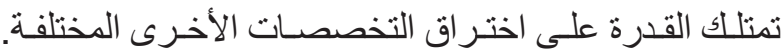

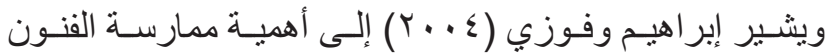

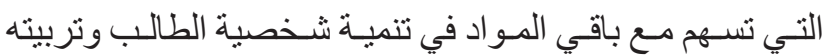

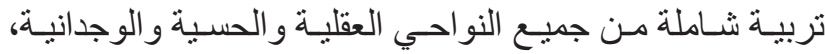

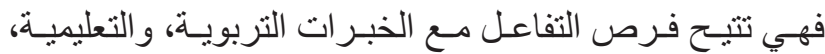

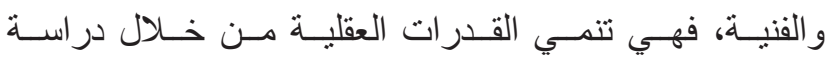




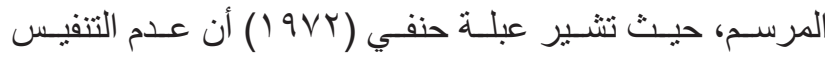

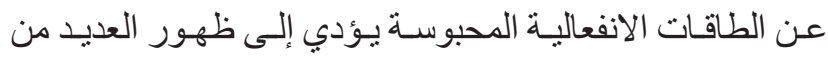

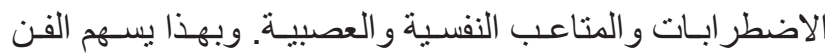

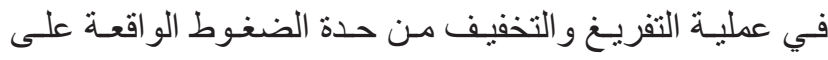

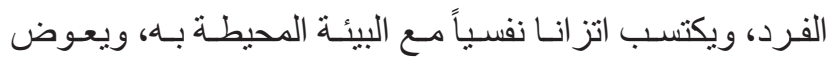

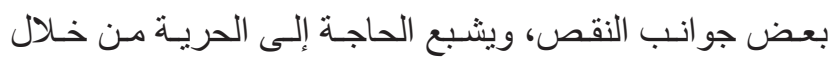

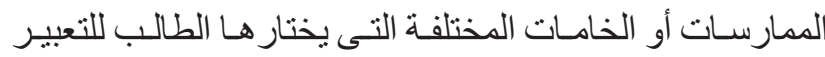
عن نفسـهـ داخل المرسـم الحـر.

و انطلاقـا مـن أن الفـن لا يصـدر مـن التفكيـر الو اعـي وحـده،

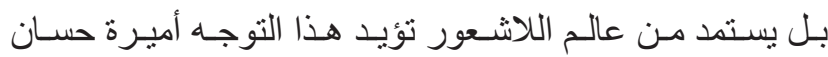

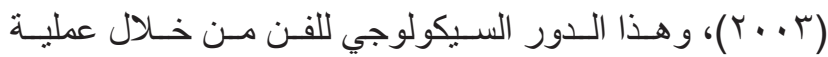

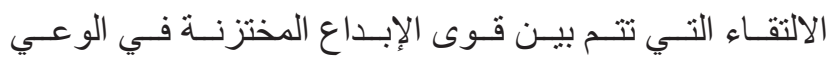

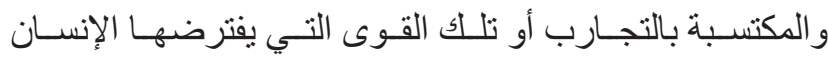

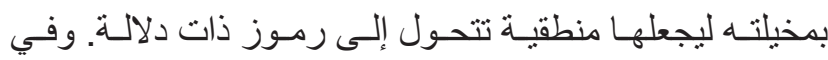

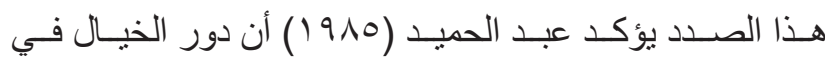

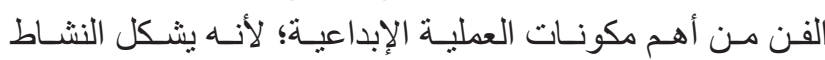

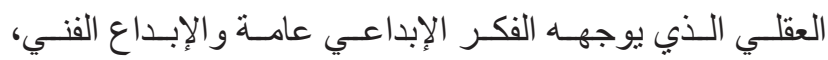

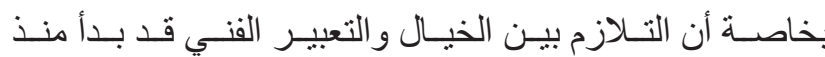

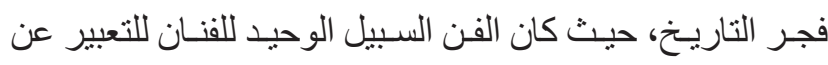

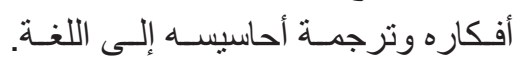

و لا يمكن أن ننكر أن ممارسـة الفنون هي من مظاهر استخلال

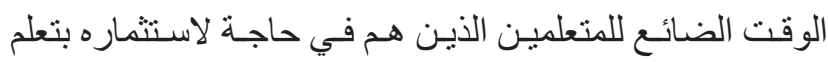

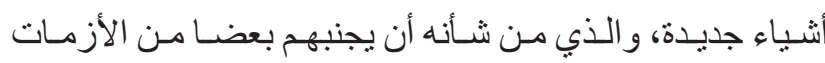

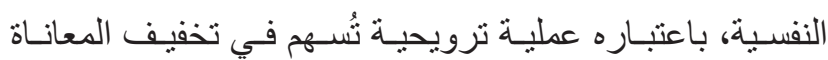

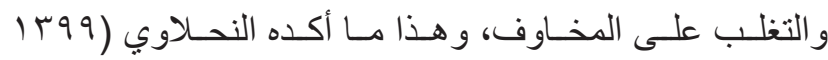

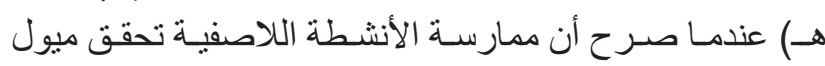

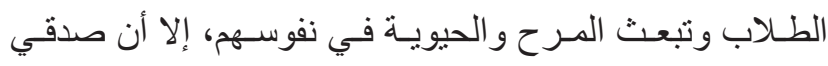

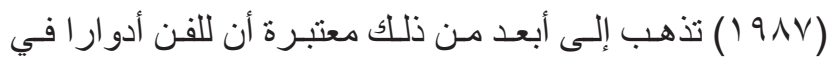

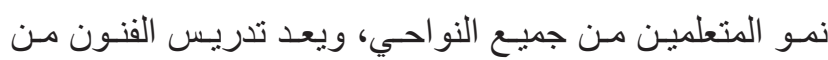

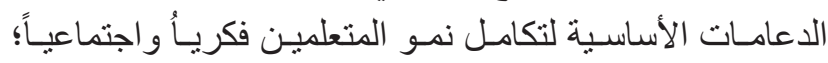

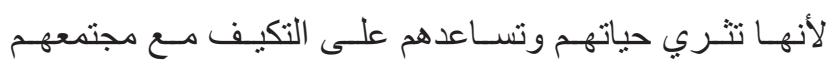

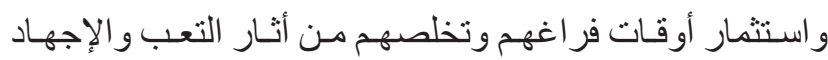

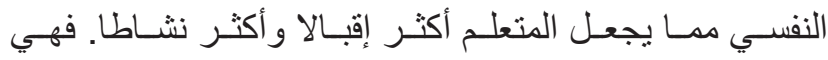

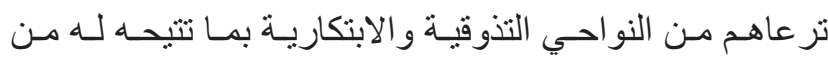

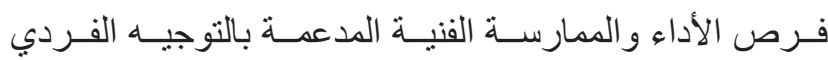

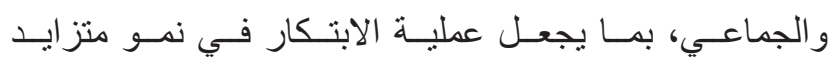

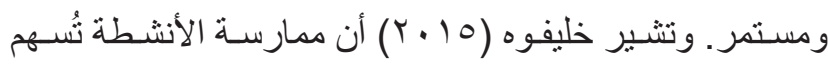

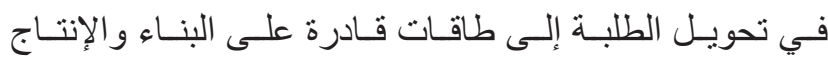

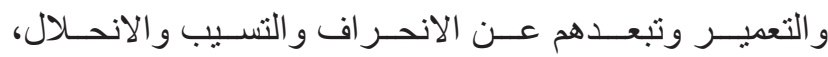
وتحفز هـم على التحصيـل الدر اسـي.

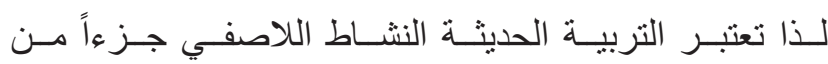

بشكل شـولي متكاملـل وواعٍ و هادف، من أجلـ تغييره ونطويره.

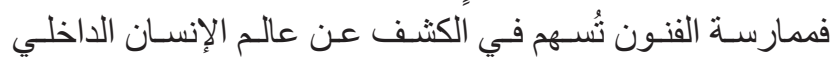

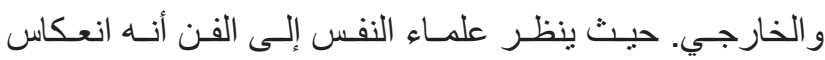

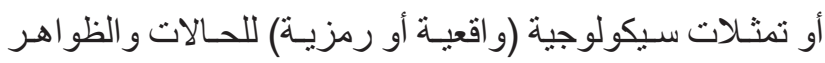

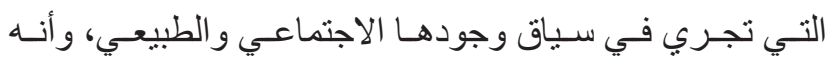

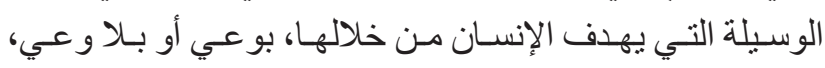

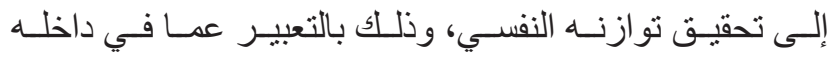

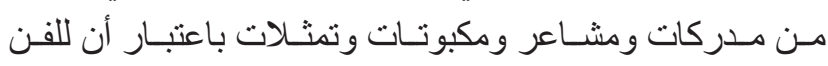

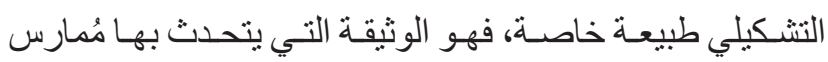

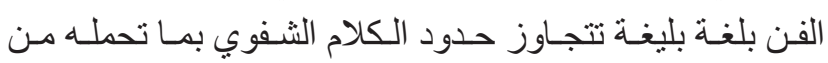
دلالات ومعـان تعجز اللغـة عن التصريـح بها. ويفسـر بعض علمـاء النفس دوافـع التعبيـر الفنـي أنهـا وسـبلة

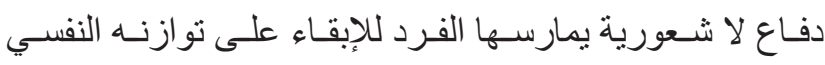

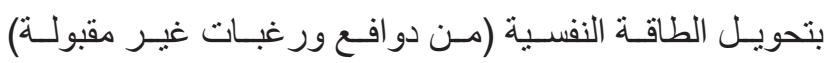

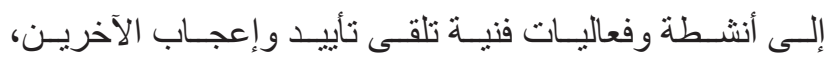

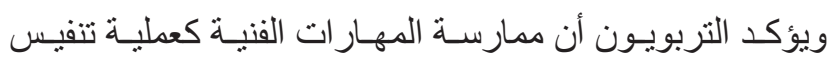

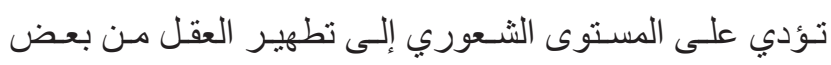

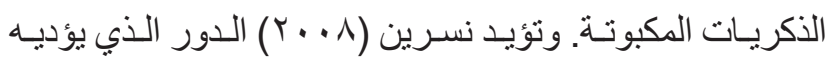

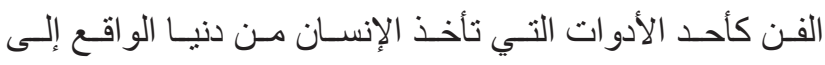

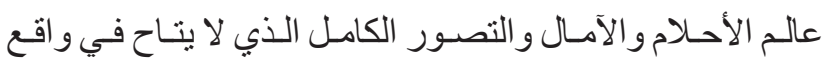

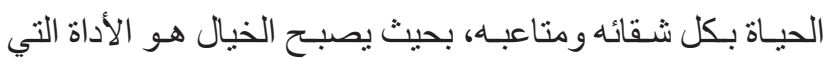

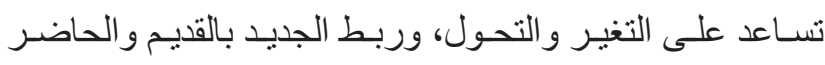

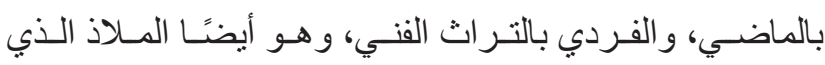

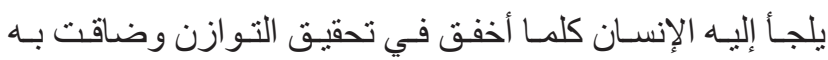

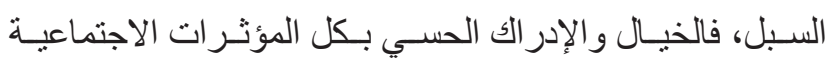

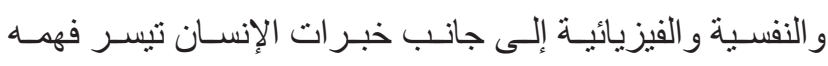
للخلق الفنـي والإبـداع.

وتتبنـى التربيـة الحديثـة فكرة لالفن و الترويـح)، وذلك لأهميـة

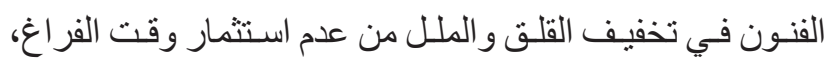

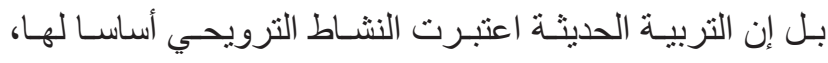

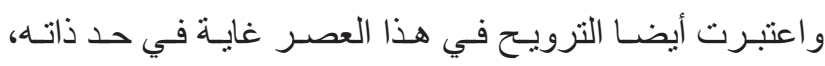

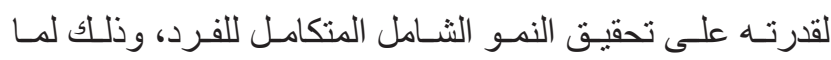

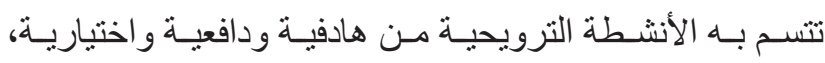

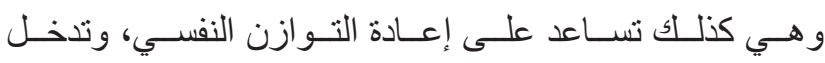

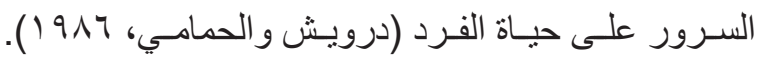

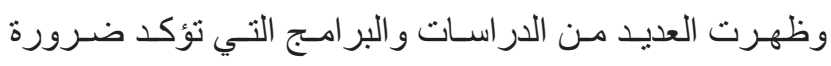

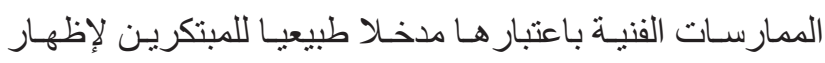

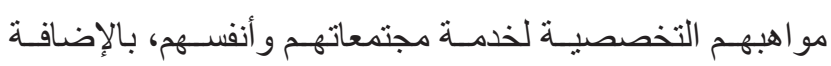

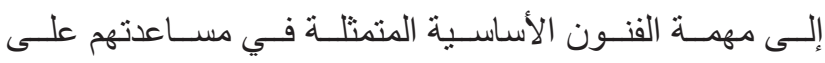

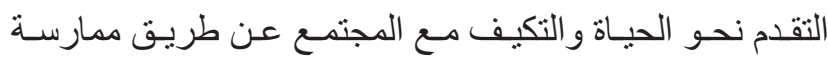

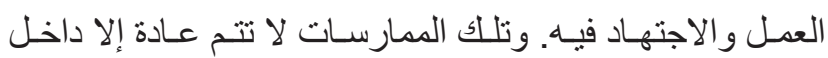




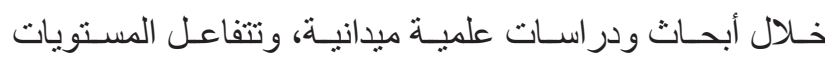

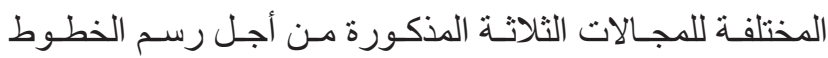

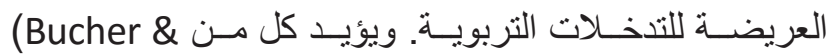
Richard, 1997)

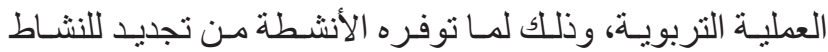
و الحيويـة، و إعـادة الثـحن الحيويـة و الحركيـة و العقليـة للأفر اد.

لـذا أصبـح مـن أهـم الأهـداف الرئيسـة للمؤسسـات الأكاديميـة

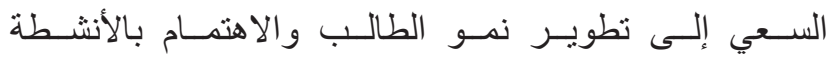

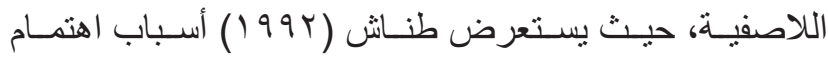

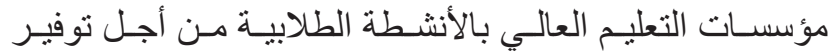

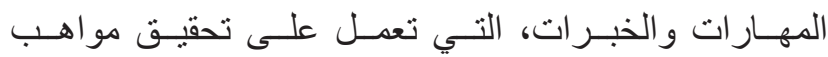

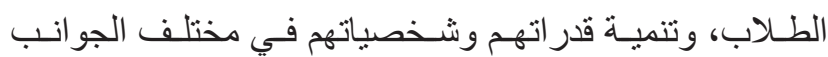

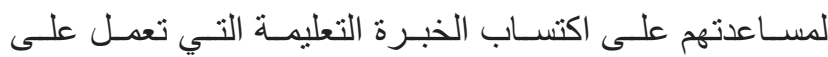

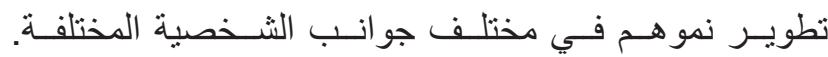
وتخلص در اسـات كل مـن (Pamela, Taylor, \& Carpenter, 2005, Hubbard, 2005, Michelle 2003, Gotlieb, 2002, إلىى Kernan (2002), Nicholson, 2002, Huston, 2002)

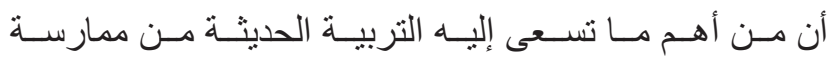

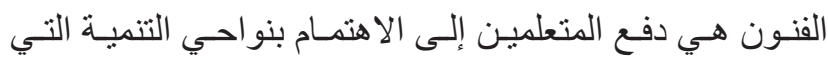

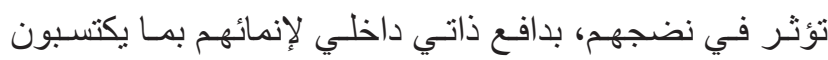

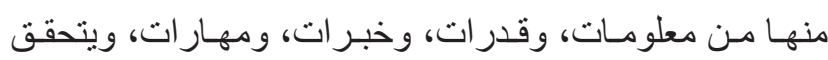

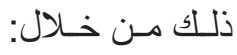

تعريـف المتعلميـن بالقيم الجماليـة و الفنبـة لمكونـات البيئـة

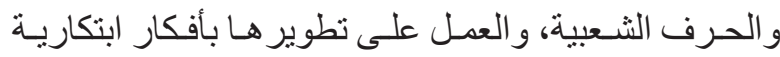
وفقاً لقدر ات المتعلمين.

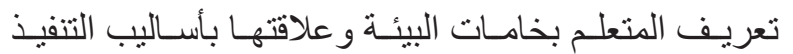

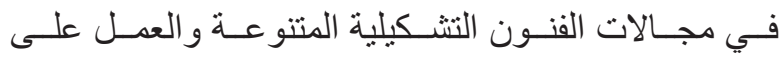
ترشـيد اسـتهلاكها.

تنميـة قدر ات المتعلميـن على التــوق الفنـي للقيم الجماليـة،

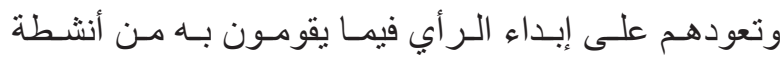

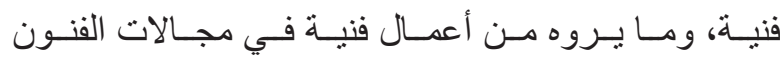

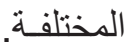

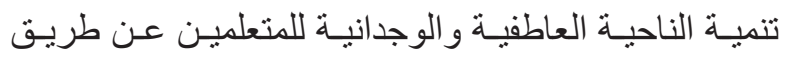

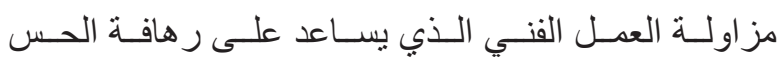

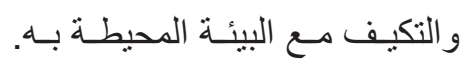

تدريـب حـواس المتعلميـن على الاسـتخدام غيـر المحـدود والاتجـاه نحـو الابتكار و الإبـداع.

تدريـب المتعلـم علـى اسـتنمار أوقـات الفـراغ فـي إنتـــاج الأعمــال الفنبــة.
مناهجهـا لأنهـا تســاعد علـى تطويـر وتحسـين كثيـر مـن

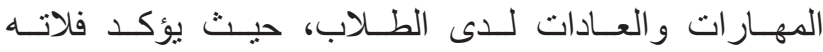

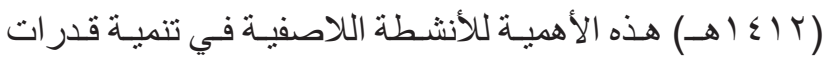

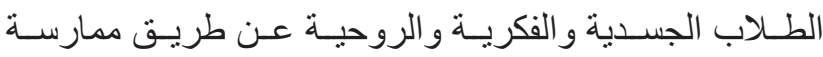

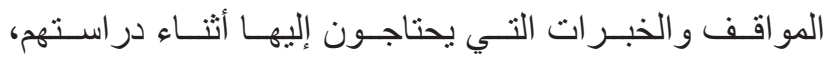

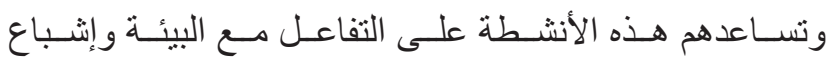

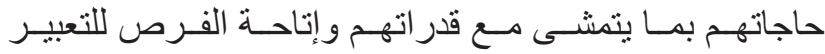

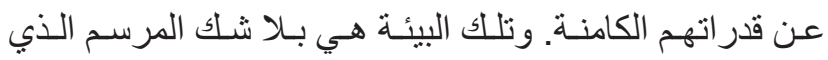

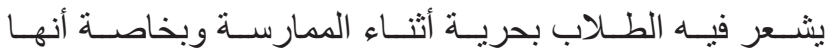

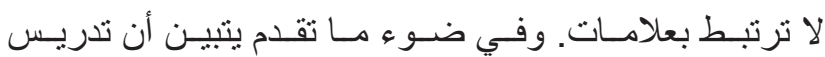

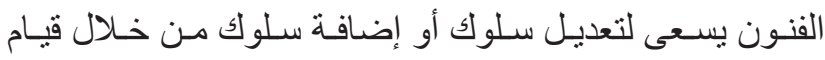

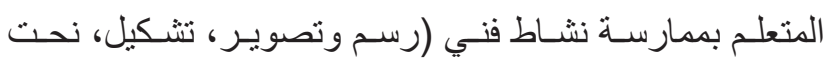

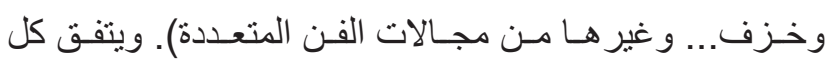

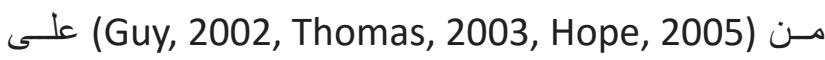

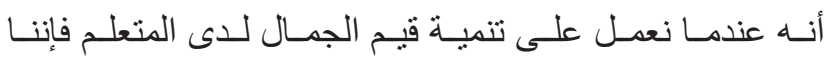

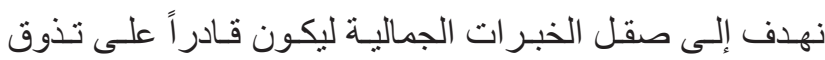

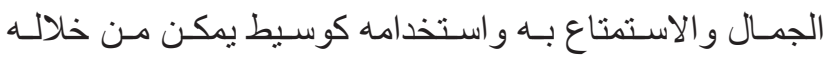

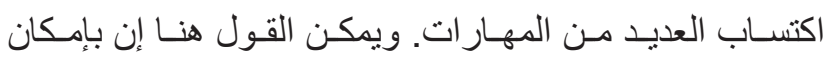

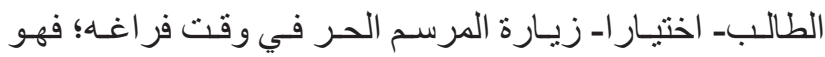

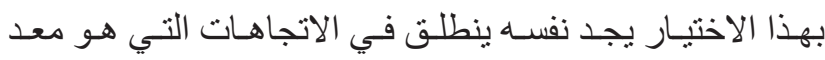

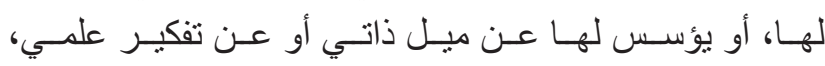

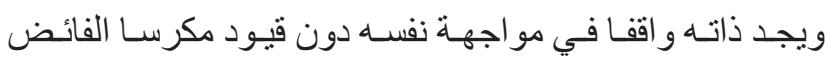

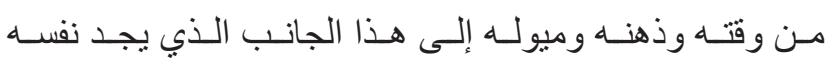

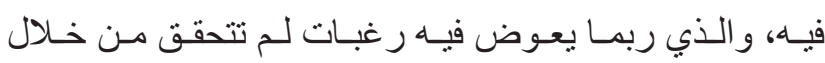

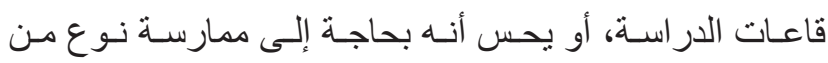

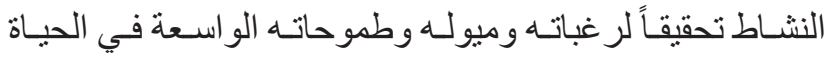

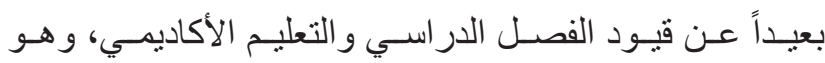

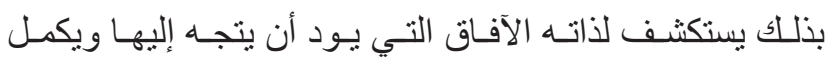

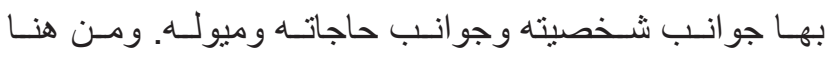

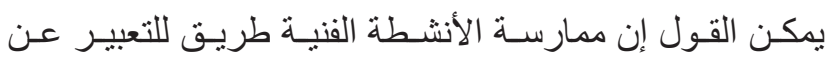

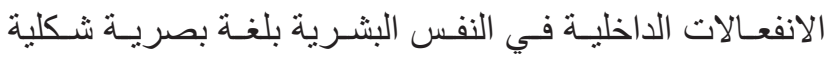

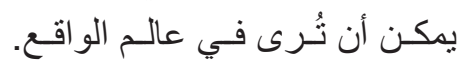

المحسور الثانـي: الأهميـة التربويـة لممارسـة أنشـطة الفنـون

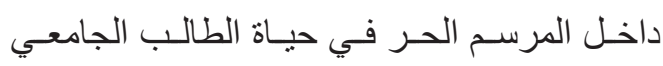

إن هنـاك وظيفـة تربويـة للفـن بدركهـا العاملــون فـي المجــال

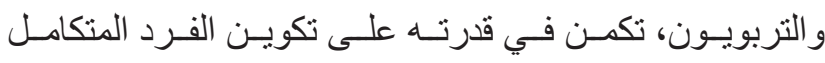

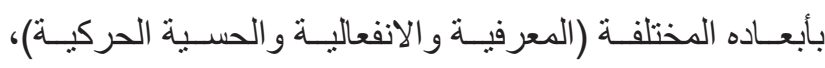

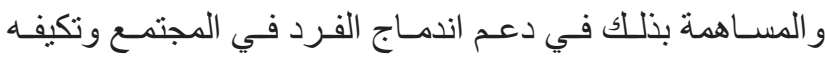

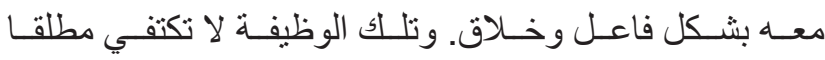

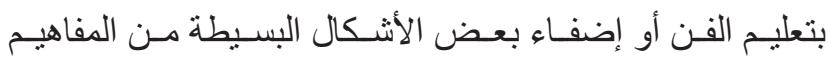

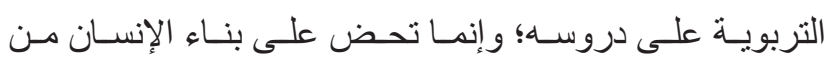




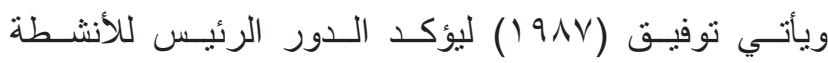

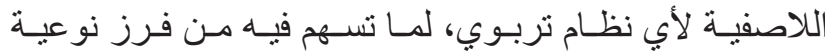

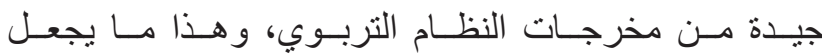

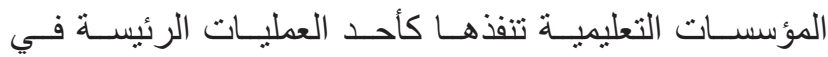

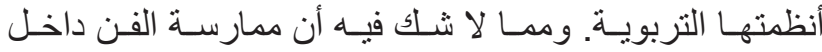

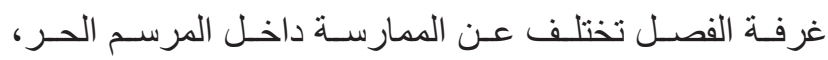

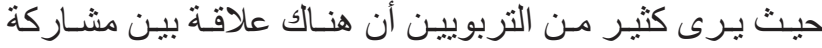

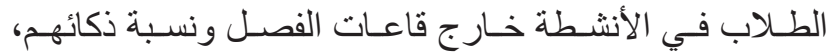
ويؤكد شـحاتة (991 (19) أن الطـلاب المشــاركين في الأنشـطة

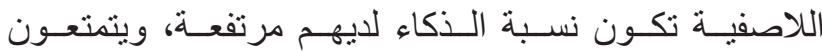

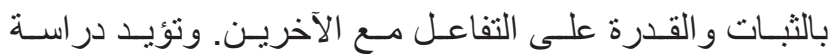

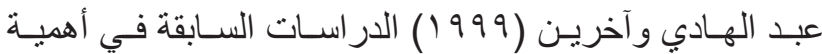

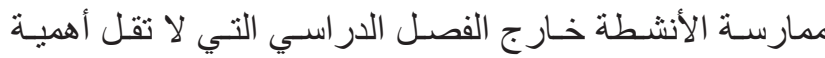

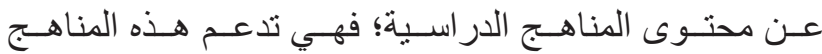

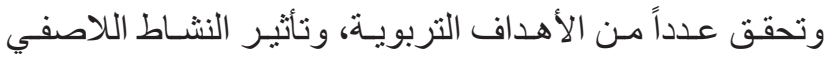

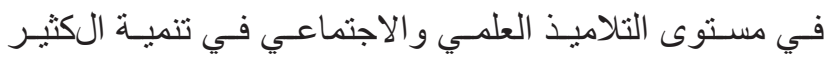

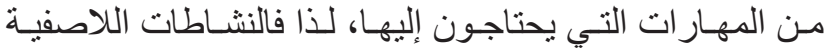
تُعـد جـز عا مهمهـا مـن العمليـة التعليميـة.

وتكمـن ميـزة اللجـوء العـام للمرسـم في الحريـة التـي يمتلكهـا

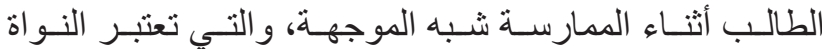

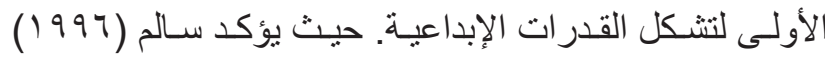

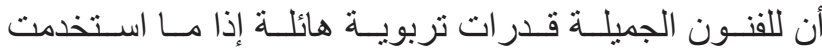

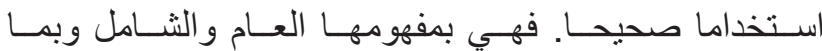

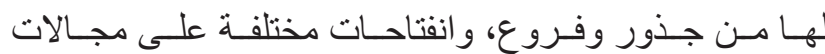

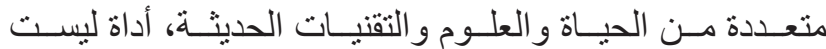

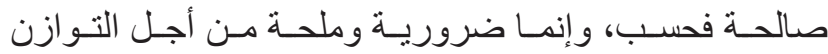

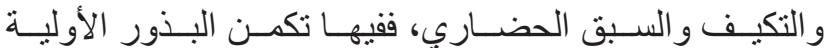

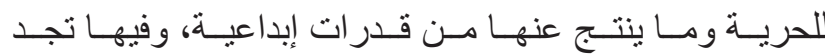
الخبرات التجريييـة التـي تعتبر أساسـا لتكوين الإنسـان، ومسن

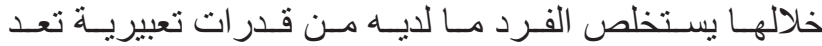

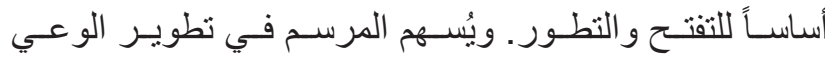

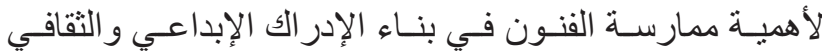

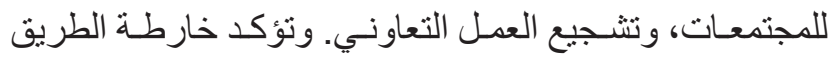

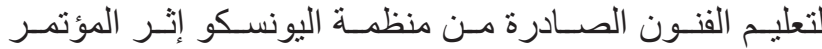

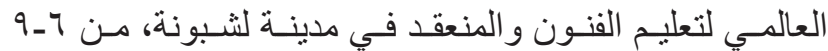

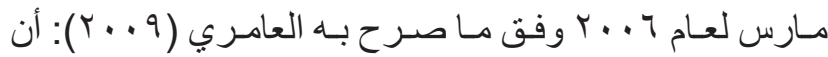

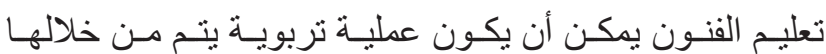

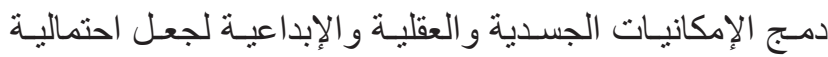
العلاقـات الميـزة و الدينامكيـة أكثر فيمـا بيـن التربيـة والثقافــة

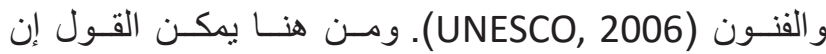

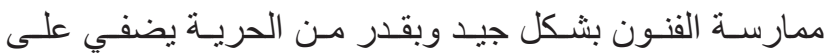

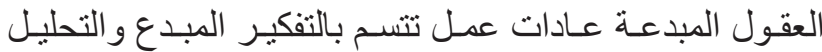

• إكسـاب المتعلمين القدرة على سـرعة الملاحظــة والتمييز و الإتقـان مـن خـلال ممارسـة الأنشــة في مجـالات الفـن

المختلفـة.

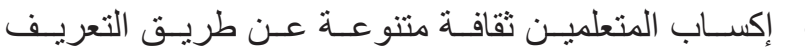
بالقيـم التشـــيلية العالميـة. ه اكتشاف المتعلمين الموهوبين فنباً ور عايتهم.

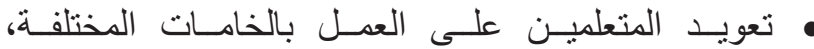

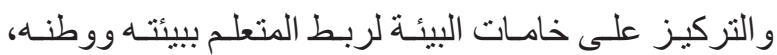
و المشــاركة فـي تجميـل البيئـة و المجتمــع.

و على الرغـم مـن أهميـة الأنشـطة في حيـاة الطالب فإنتـا مـا

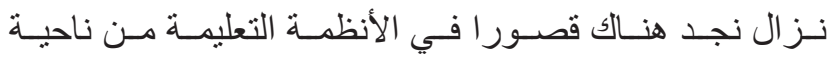

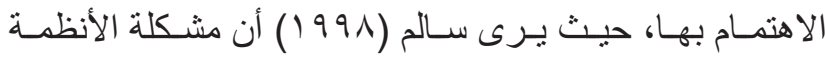

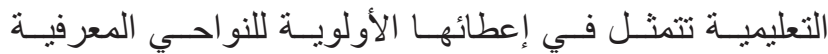
غافلـة دور الأنشطة الفنبـة، رغم أن الفنون بشكل عـام يمكنهـا

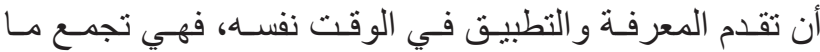

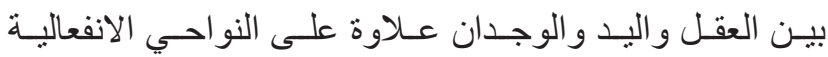

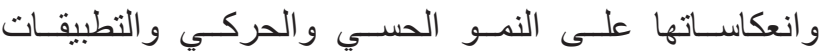

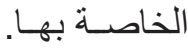

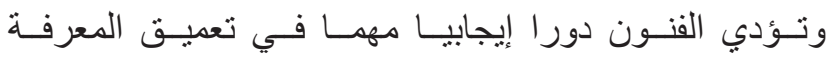
الإنسـانية بيـن المجـالات العلميـة المختلفـة، حيـث أكـد الكثيـر

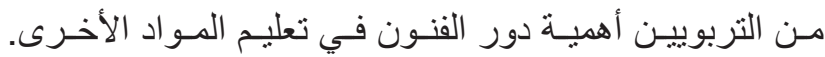

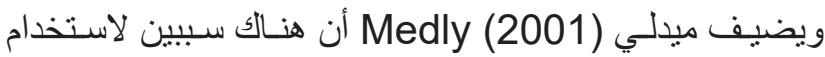

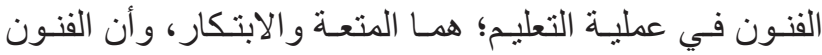

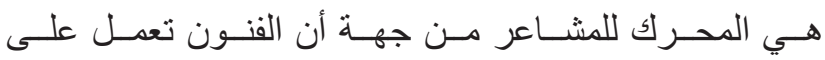

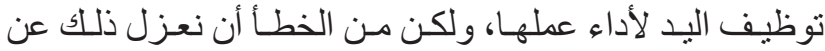

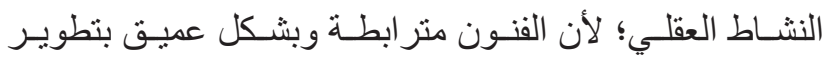
العقل. وقد زاد الاهتمـام مؤخر ا بالأنشطة اللاصفيـة لتأثنير هـا

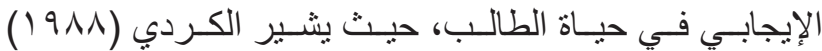

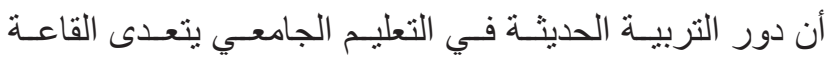

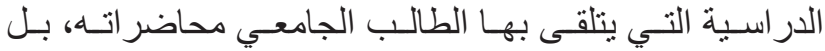

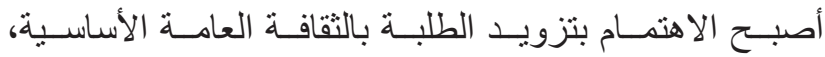

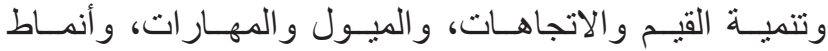

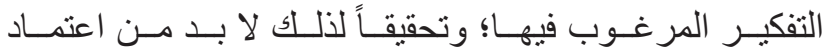

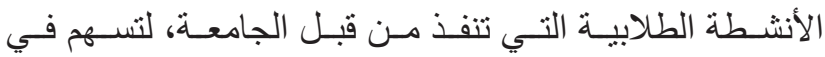
تطويـر طلبتهـا وصقل شـخصنياتهم.

ولـو لا أهيـة الأنشـة اللاصفيـة وتأثثير هـا في حيـاة الطالب؛

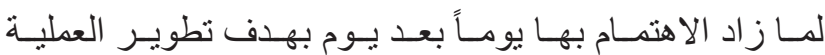

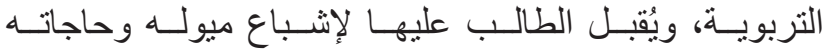

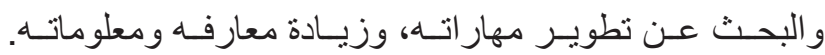




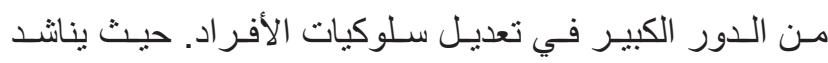

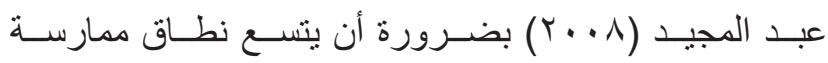

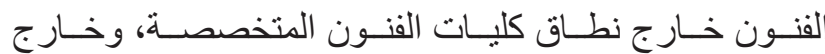

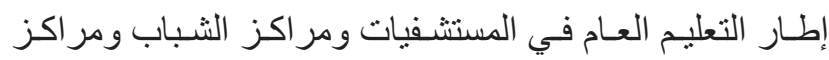

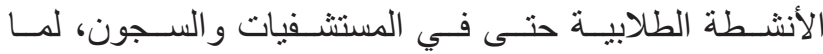

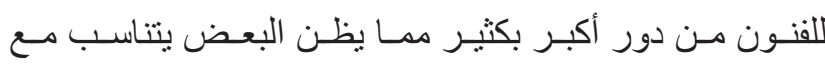

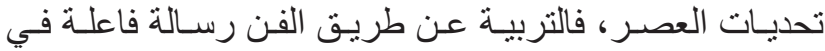

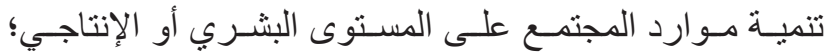

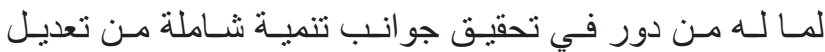

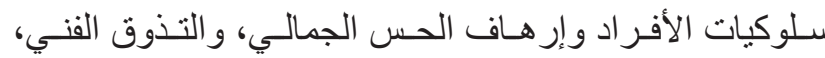
إضـافـة إلى تنميـة قدر اتهم على التفكير الإبداعي الذي يمثنل

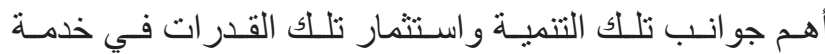

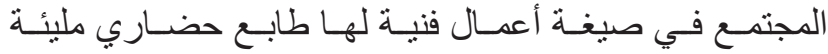
بالعمـق الثقافي؛ يمكن أن يكون مـوردًا اقتصـاديًا يفيد كلا مـن اعن

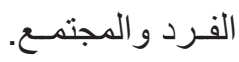

وتأييدا لأهميـة المرسـم الحـر في تثـجيع الجانـب الاجتماعـي

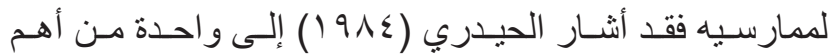

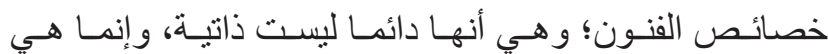

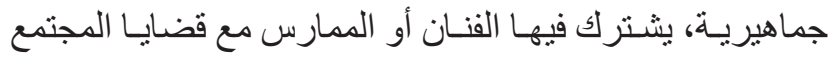

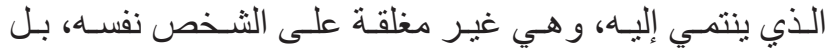

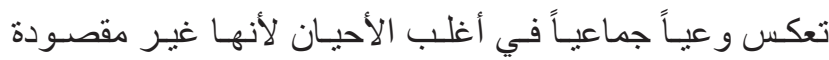

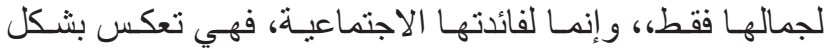

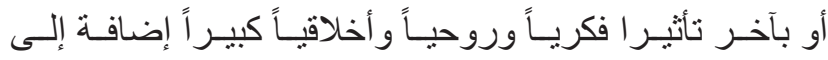

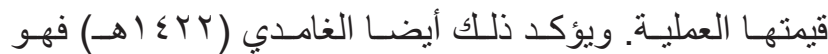

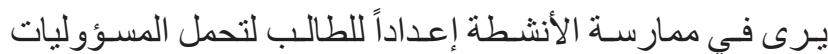

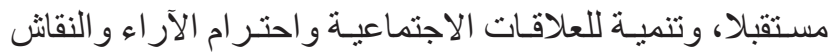

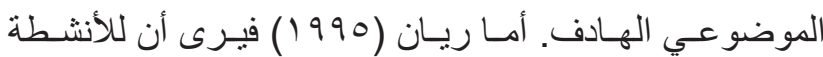

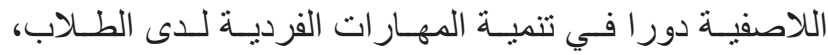

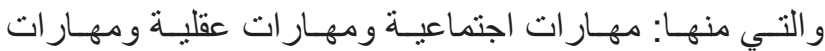

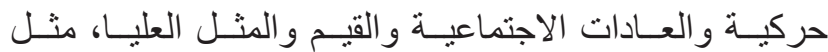

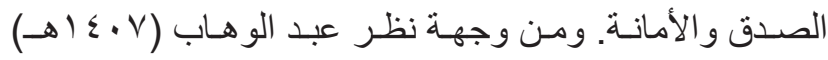

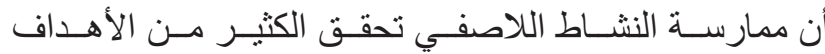

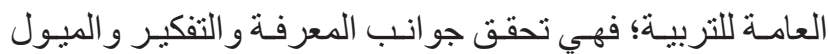

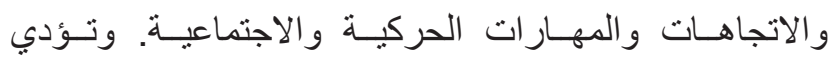
الأنشطة اللاصفيـة دور ا كبيـرا في بنـاء الفرد جسميا و عقليـا

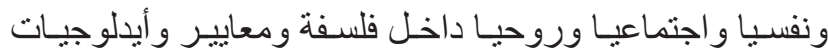

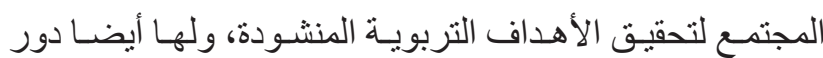

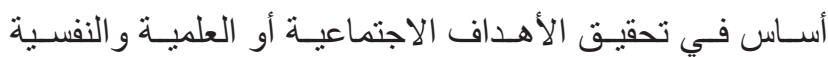

للعمليـة التربويــة.

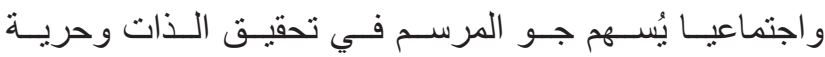

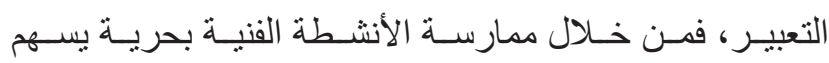

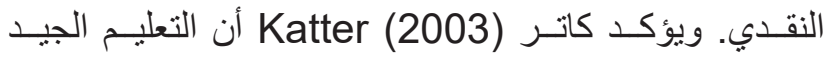

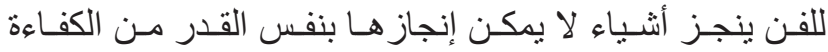

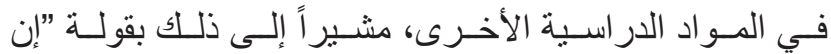

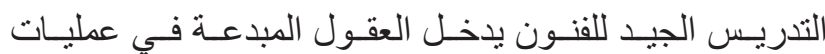

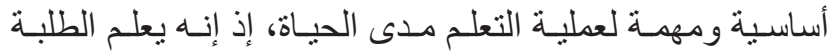

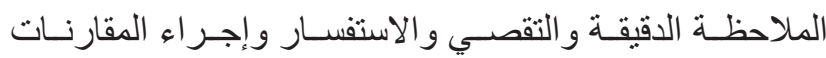

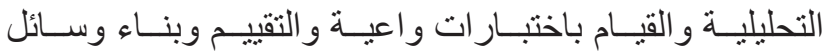

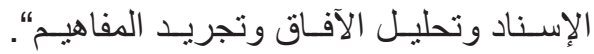

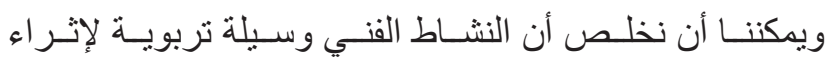

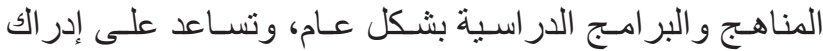

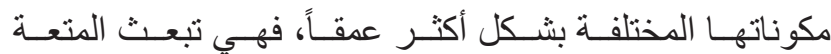

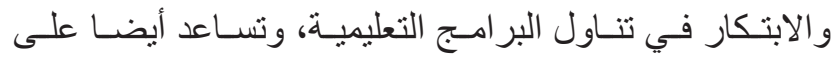
تحريلك المشـاعر بشكل إيجابسي نحو تقبـل الدر اسـة الأكاديمية،

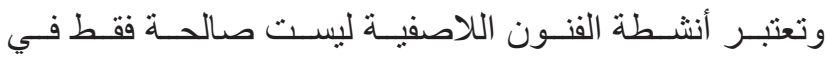

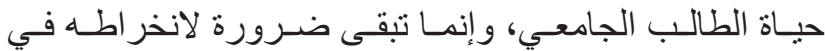
المجتمـع الخارجـي.

المحسور الثالث: الأهميـة الاجتماعيـة لممارسـة أنشطة الفنـون

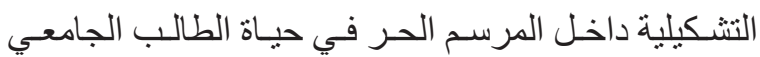

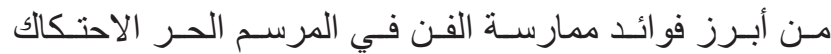

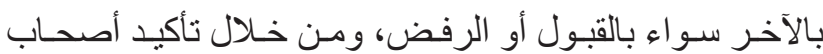

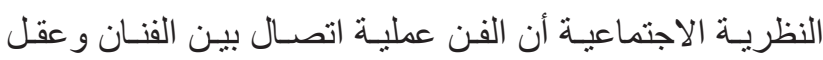
ووجـدان أفـر اد المجتمـع، فـإن الفنانيـن لا يبدعـون مـن أجـل

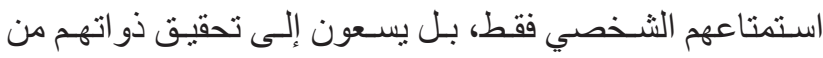

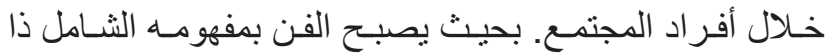

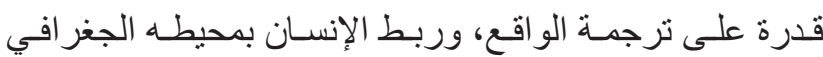

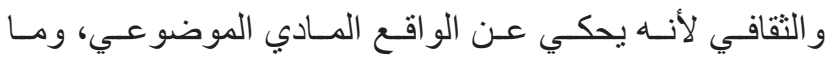

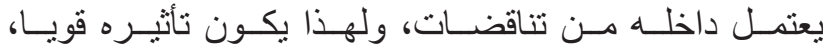

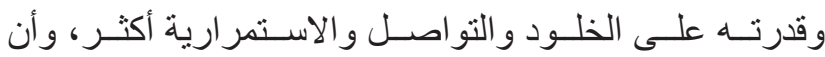

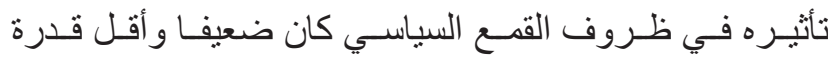

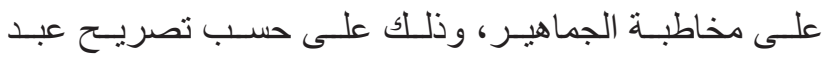

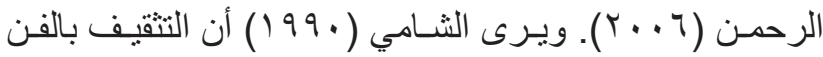

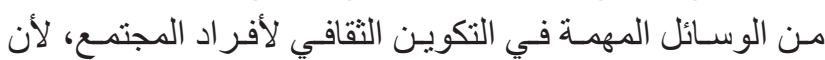

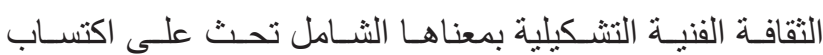

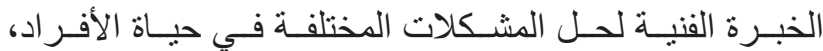

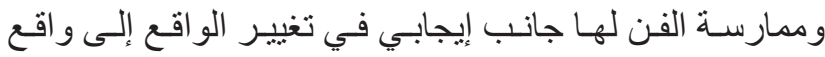

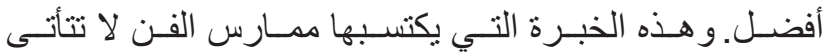

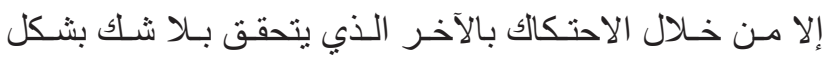

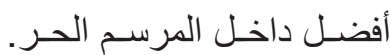

من هنـا يشجع الباحثُون على ممارسـة الفن ليس فقط داخلـ

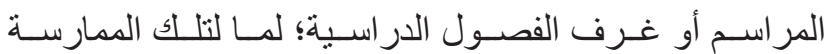


الفـرد، وتتضــح لديـه ظاهـرة مهمـة في الحيـاة، وهـي أن الحيـاة

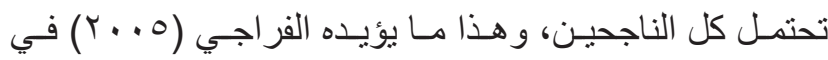

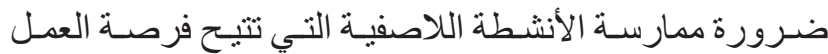

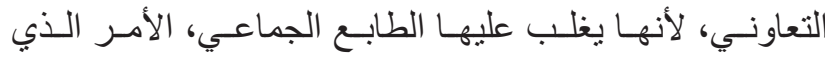

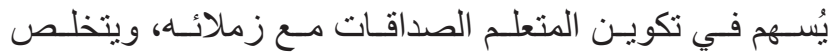
بعض المتعلميـن مـن الانطـو اءو الخجـل، وتعميق مبدأ التشـاور

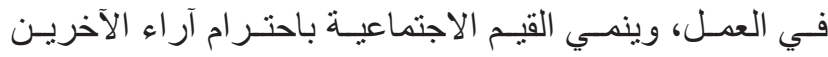

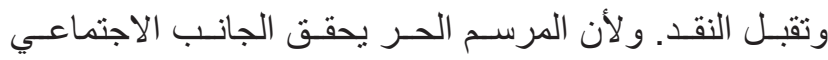

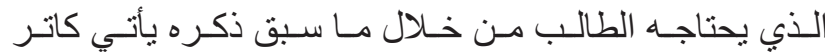
Katter (2003) ليلخـص قـوة الفـن التـي تكمـن فـي تهيئسة أشـخاص يحملـون مجمو عـة مسن الصفــات الاجتماعيـة منهـا: • أشــخاص بإمكانهـم أن بعملـو ا بثقــة واسـتقلالية وتســامح و احتــرام مــع الآخريـنـ.

• أشـخاص يفهــون بـأن حريـة التعبيـر لا تتحقـق مسن دون تحمـل مسؤولية.

• أشـخاص بتسـمون بالانضبـاط الذاتي وبإمكانهـم أن يتحملـوا

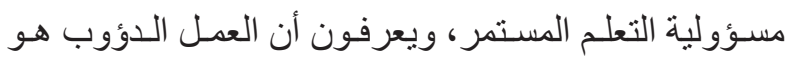

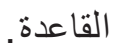

• أثــخاص لايهـم القدرة على التوصـل إلى حلـــل معقولـة

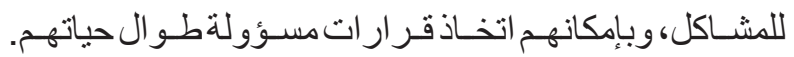

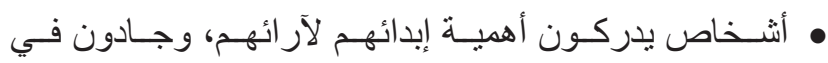
تحقيـقت أهدافهم الثــصية والاجتماعبـة.

• أثــخاص يدركـون أهميـة العهـل بالتعــاون مـع الآخريـن،

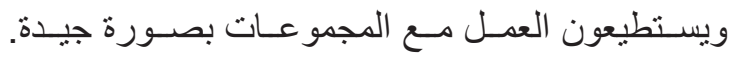

• أثــخاص بإمكانهـم الاتصــال بالآخريسن بكفــاءة بوســائل

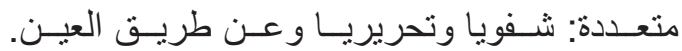

• أنثـخاص بإمكانهم فهـم وتقييـم الرسـائل البصريـة بحيـث

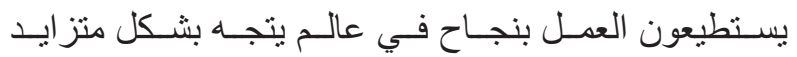
نحسو المرئيـات ووسـائل الأعـلام.

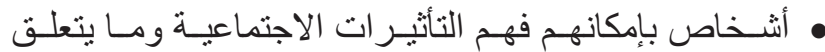

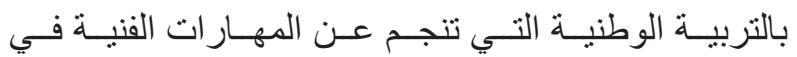

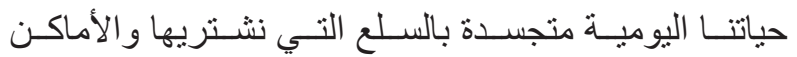

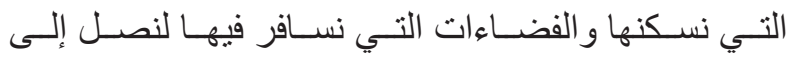

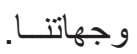

وأخيـراً يمكـن القـول إن التكامـلـ التربــوي و السـبكولوجي

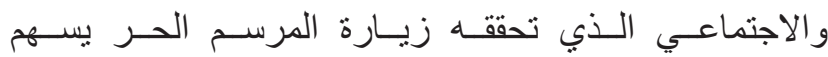

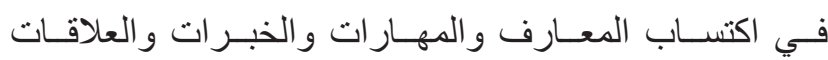

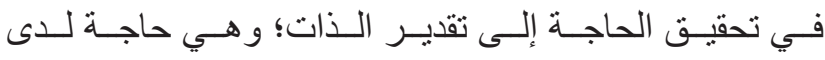
جميـع المتعلميـن تدفعهم إلـى توظيـف إمكاناتهـم وترجمتهـا

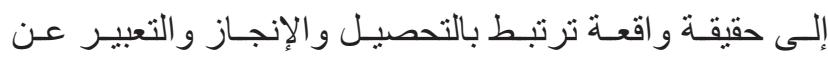

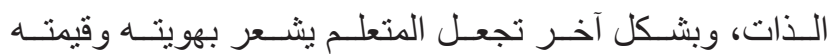

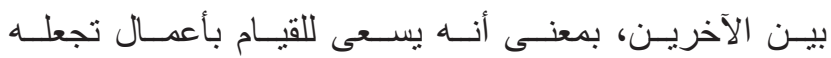

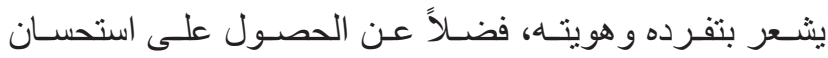

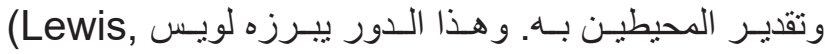

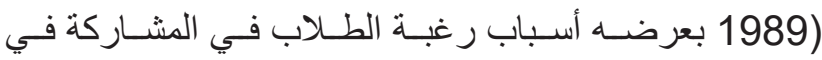

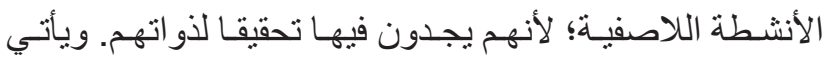

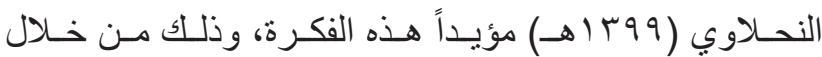

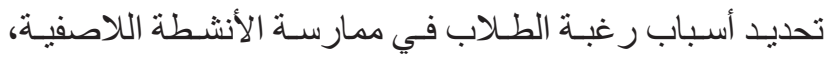

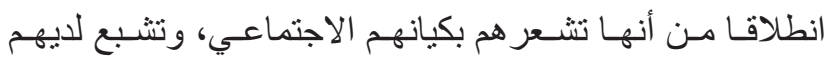
بعضـا مـن حاجاتهم النفسـية.

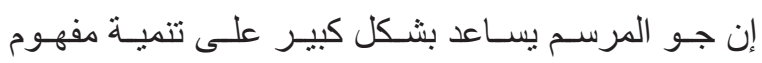

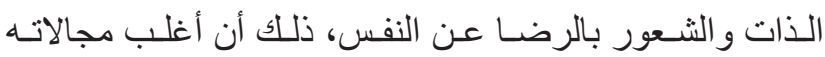

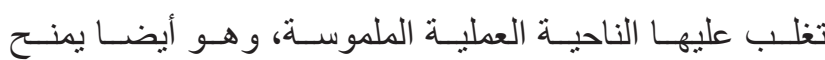

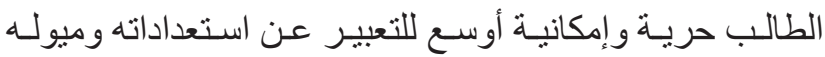

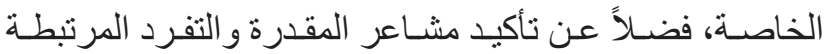

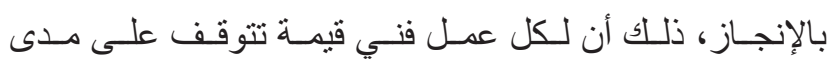

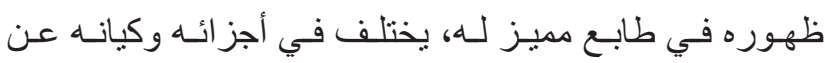

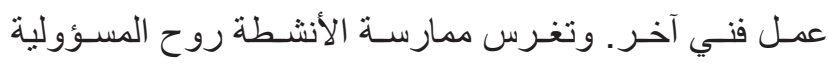

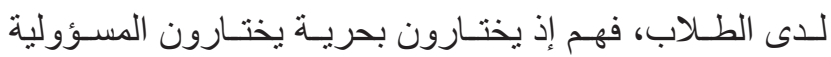

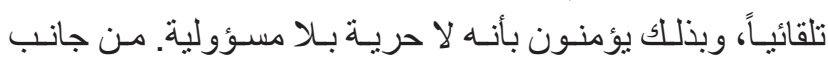

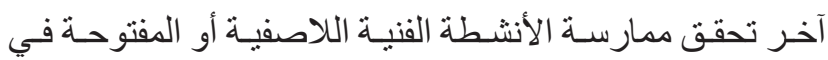

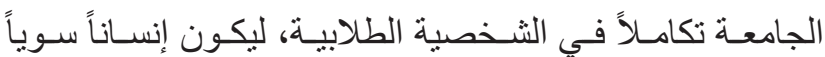

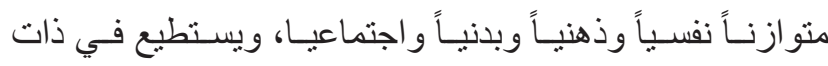

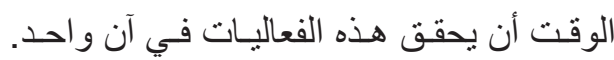

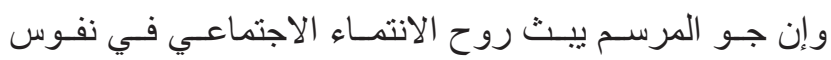

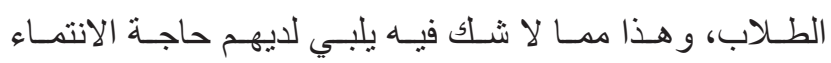

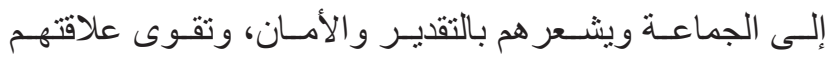

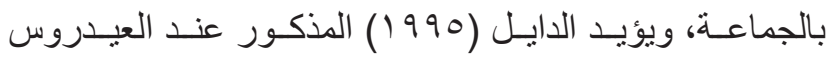

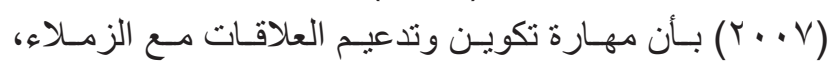

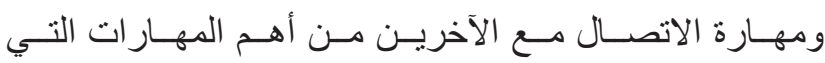

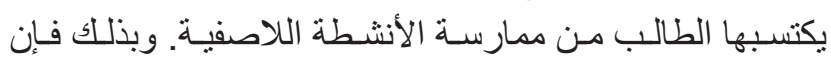

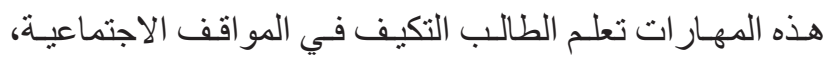

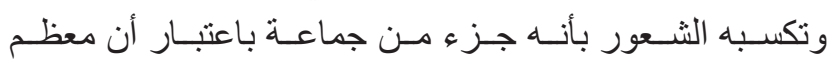

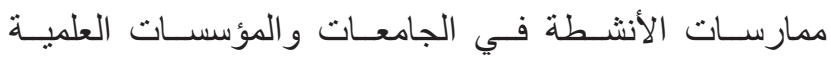

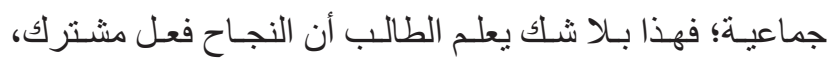

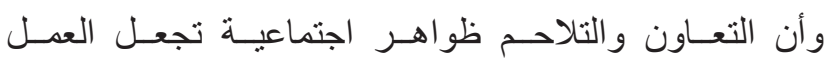

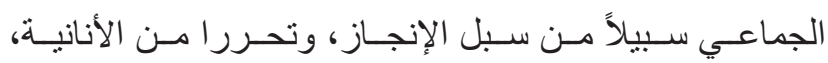

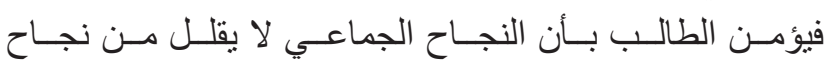


• ينبخـي مر اعـاة أن يتيـح النشـاط الطلابــي فرصـاً سـانحة

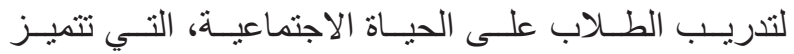
بالتعـاون و الصبـر و الإيثـار ، و التـي تدعـم القبـم و المبـادئ التربويسة و الإســلامبية. • الاهتمـام بـأن بكـون النشـاط الطلابـي مجـالاً واسـعاً للتعلم المثــر عـن طريـق الخبـرة المباشـرة، و العمـل الإيجابـي. ينبغـي أن يكـون النشـاط الطلابـي وسـيلة لإز الـة الحواجـز بيـن الطـلاب و أسـاتنتهم، و إقامــة العلاقـات و الصــلات

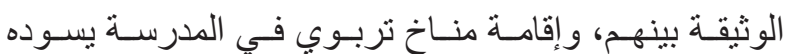

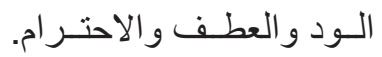

في نهايـة هـذه الدراسـة يمكـن الخـروج بتوصيـات لتفعيـل دور المرسـم الحـر في حيـاة الطالب الجامعي، وتتمثل في النقـاط الآتية: • ضـرورة حـث وتشـبيع الطسلاب على المشـاركة في الأنشـة

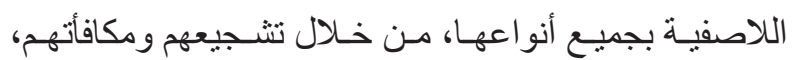

$$
\text { و إيجـاد الحو افز الماديـة و المعنويـة. }
$$

• احتسـاب ممارسـة الأنشـطة اللاصفيـة في كثـوف درجـات

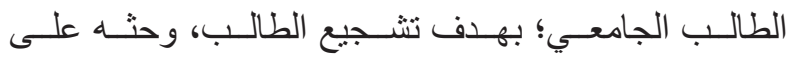
الانخـر اط بتلك الأنشـة، وربطهـا بالجو انب الأكاديميـة التي ولي

بدرسـها. • تو عيـة الطـلاب بأهميـة الأنشـطة الفنيـة في صقل المعسارف و المو اهـب، وتنميـة الهو ايـات المختلفـة فـي حيـاة الطالـبـ الجامعس. ضـرورة مشـاركة جميـع المتخصصيـن في مجـالات الفنون في الجامعـة؛ للمشـاركة في وضـع خطط الأنشطة اللاصفية

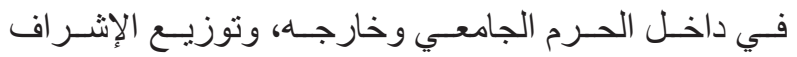
بينهم كلا على حسـب تخصصسه و اهتماماتـه.

• تخصيـص أوقـات مناسـبة لجمبـع الطـلاب على المسـتوى

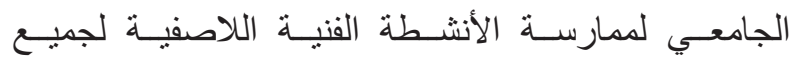

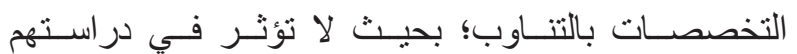

الأكاديمبـة.

در اســة معوقـات وصعوبــات ممارســة الأنثـــة اللاصفيـة

$$
\text { بالنسـبة للطالـب الجامعـي. }
$$

در اسـة العلاقـة بيـنـ الأنشـــة الفنيـة اللاصفيـة و الجوانـبـ

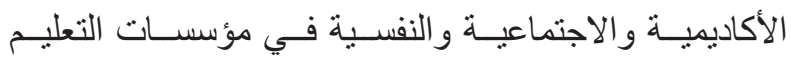
العالـي.

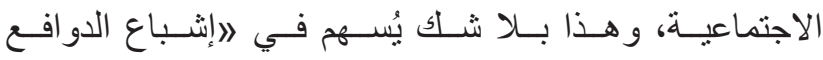

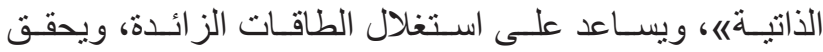
التـوازن النفسـي ويحقق الرغبـة أيضــا في التكيـف مـع أنمـاط السـلوك الاجتمـاعي، ويوسـع معـارف الطالـب، ويحقق الـدور

$$
\text { التربـوي المنشــود. }
$$

\section{نتائج الدراسة والتوصيات}

لكون هـذه الدر اسـة مـن الدر اسـات التنظيريسة التـي سـوف بعتـــ

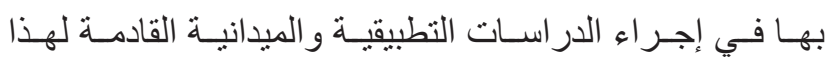
المشـروع؛ فـإن النتائسج الأوليـة تشـير إلـى أن للمر اســم الحـرة

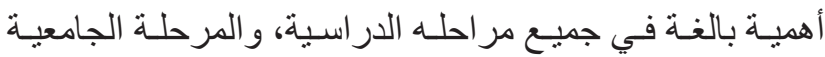

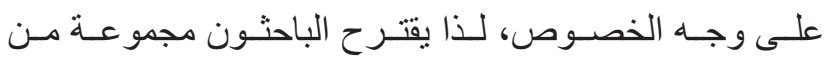

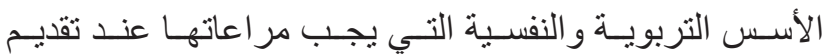

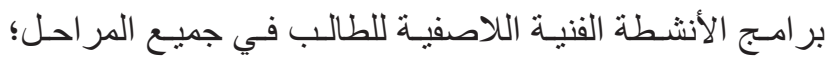
حتـى تـؤدي الأنشــطة الـدور الفاعـل المرجـو منهــا، وبمكـن تلخيصهـا في النقـاط الآتيـة:

• بجب ربـط النشـاط الطلابـي بالمقرر ات الدر اسـية، وبالبيئة

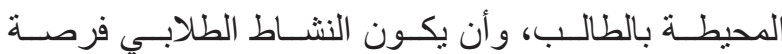
جيـدة لتوظيـف المعلومسات و المعسارف بالبيئة. • ينبخـي أن يكـون النشـاط الطلابـي وسـيلة محببـة وليســت

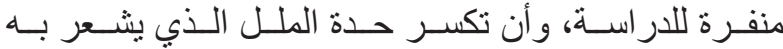

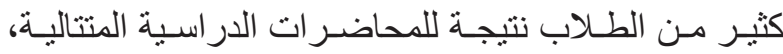
وأن تبعــث فـي نفس الطالـب البهجـة و السـرور و الدافعيـة لممار سـتنها. • أن يكـون النشـاط الطلابـي مجـالاً مفتوحـاً لتعبيـر الطـلاب عـن ميولهـم، و إثــباعاً لحاجاتهـم النفسـية والاجنماعيـة. • أن بثـجع النشــاط الطلابــي روح الابتـكار ، وينمـي الثقـة باللفـس، ويقـوي الإر ادة، ويحبـب التعــاون والإخــاء بيـن

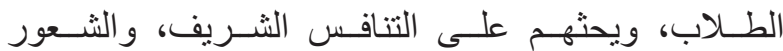
بالمسـؤولية.

هينبـي أن يتيـح النشـاط الطلابـي فرصـاً متنو عـة للكثـف عن

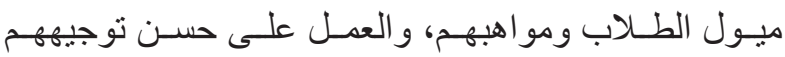

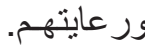
• أن توفـر الأنشـة الطلابيـة قدر ا مـن التنوع بحيـث تر اعي

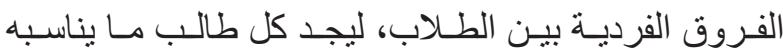
مـن أنشـطة، ومـا يتفق مـع ميولـه واسـتعداداته وقدر اتـهـ. • أن يكون النشـاط الطلابـي وسـيلة فاعلـة لعـلاج الكثيـر مـن المشـكلات التـي تو اجـه الطالب. 


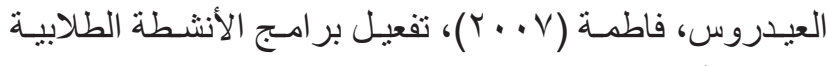

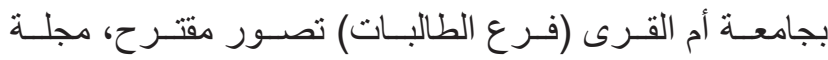

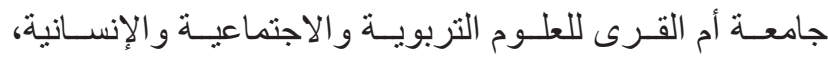

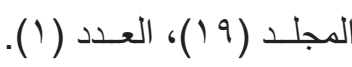

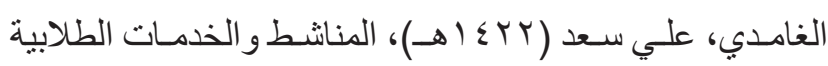

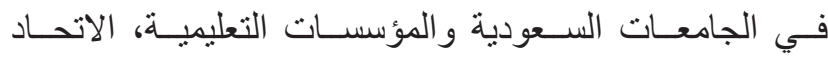
السـعودي للتربيـة البدنيـة و الرياضـــة، الريـاض، مطابــع جـاد.

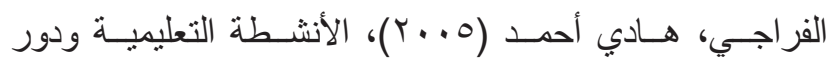

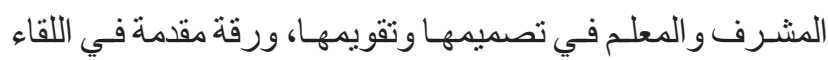
التربـوي الخامسس، دائـرة الإشـر اف التربـوي، ســلطنة عمــان.

الكردي، عصدـ (9/1 (1))، اتجاهـات الممارسـة الرياضية في

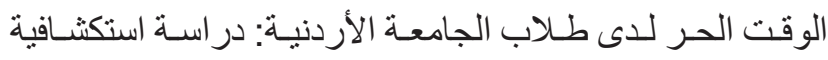

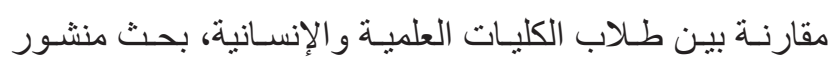

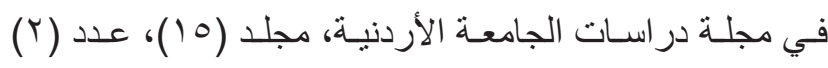

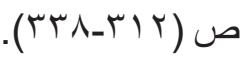

النحـلاوي، عبد الرحمـن (9V9 (1)، أصـول التربيـة الإســامية

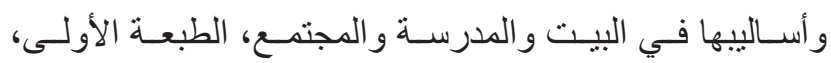
دار الفكـر، دمثـق.

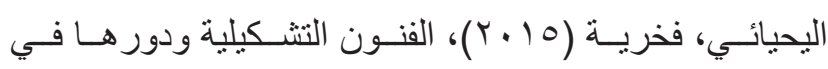

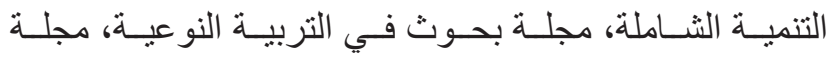

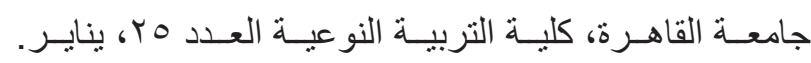

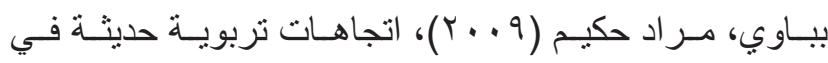

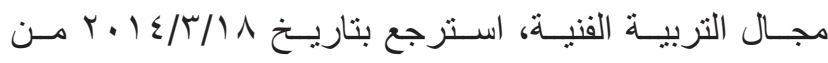
الموقع الإلكترونسي: http://kenanaonline.com/users mouradbebawy/posts/83272

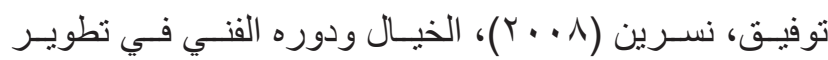

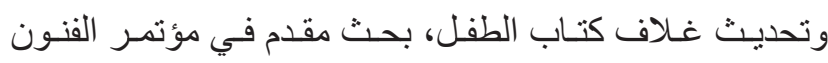

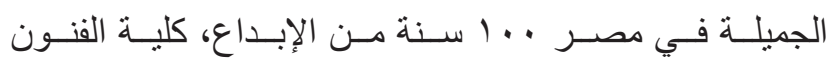

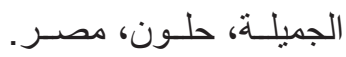

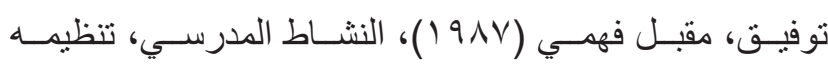
وعلاقتـهـه بالمنهــاج، دار المسـيرة، بيـروت.

جودي، حسين (997 (1)، طـرق تدريس الفنون، عمـان، دار المسـيرة للنشـر و التوزيـع و الطباعـة.
1 - الدر اسـة جـز ء مـن بحـث مهـول تمويــا داخليـا مـن كليـة

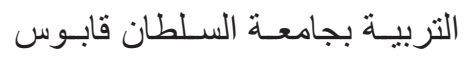

\section{المـراجع}

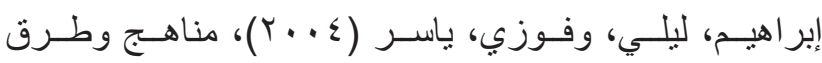

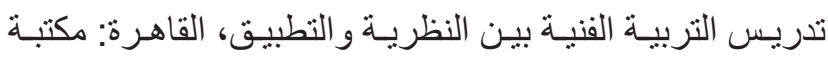

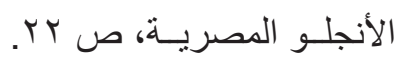

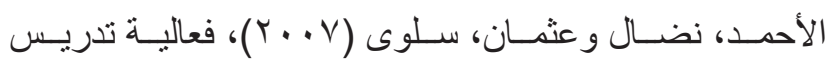

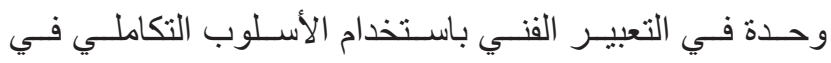

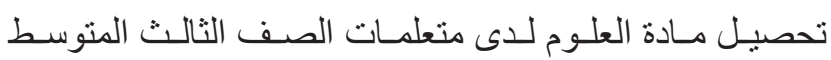

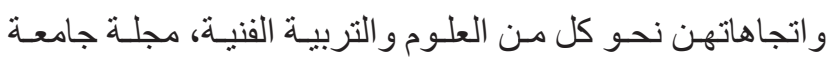

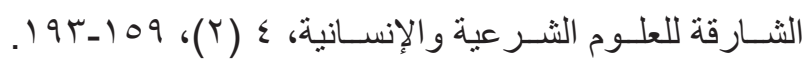

الحيـدري، إبراهيـم (ع 9 1)، إنتولوجيـة الفــون التقليديـة:

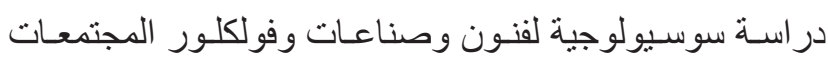
التقليديـة، دار الحـوار، سـوريـا.

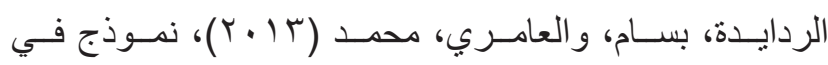

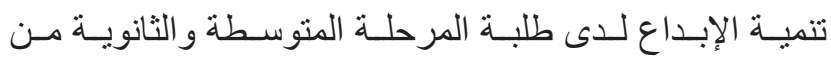

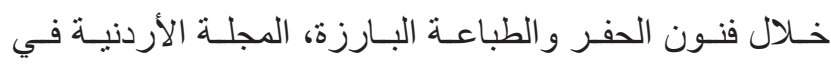

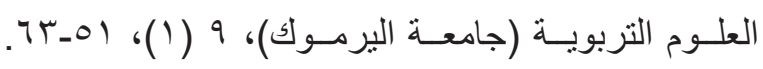

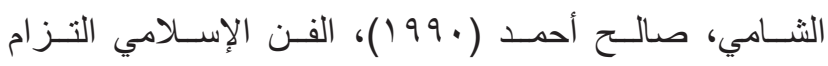

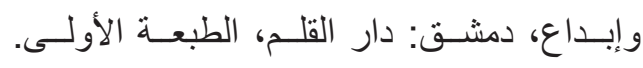

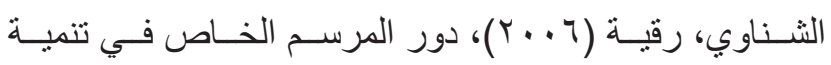

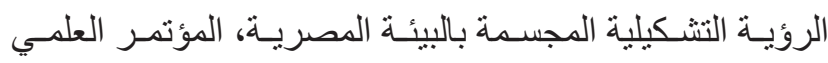

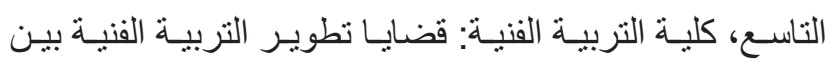

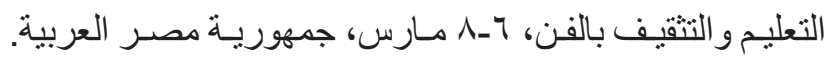

العامـري، محمـد، و أمبوسـعيدي، عبــــالله، اليحيائسي، فخريــة

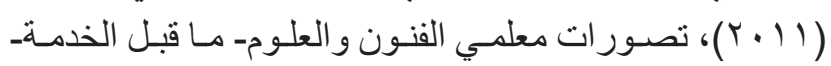

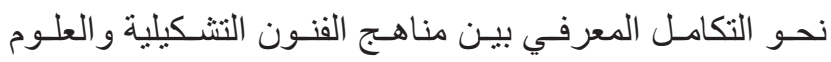

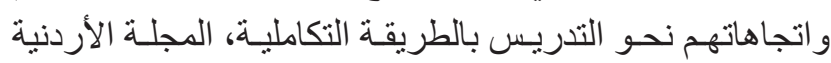

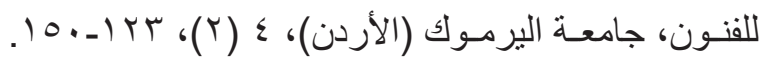

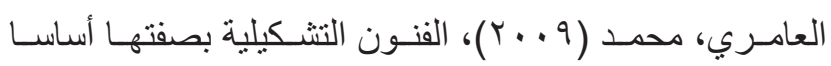

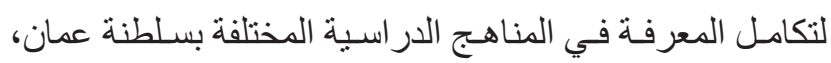

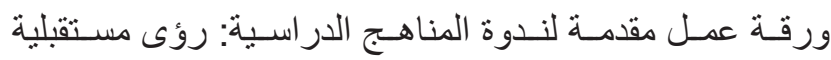




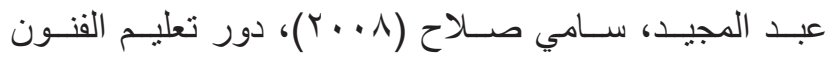
في التأكيـد على الهويـة المصريـة، بحـث مقـدم في مؤتمـر

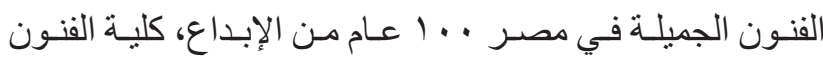

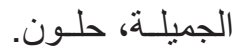

عبــد الهـادي، فتحـي، حسـن عبــد الثــافي، وحسـن شـــاتة

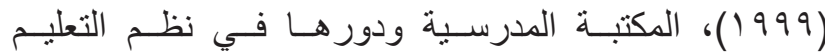

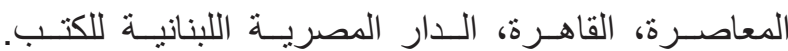

عبـد الوهـاب، جـلابل (V • ع I)، النشـاط المدرسـي، مفاهيمـه،

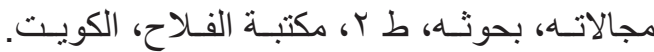

فلاتـهـ، مصطفى محمـد (ب إ؟ ا هـ)، المدخـل إلـى التقنيـات

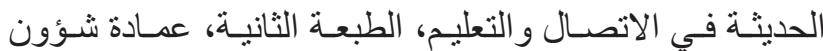

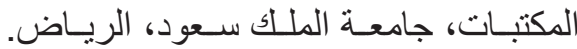

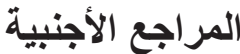

Bucher, C. \& Richard D. (1997). Recreation for today society prentice- Hall. New U.S.A. P. 6.

Clip \& Save Art Notes. (2005). Arts \& Activities,Vol.137,Aprl.P 25, Guy Hubbard.

Eckert, G. (2006). Art and how it benefits the brain. Self-help-Healing-Arts-Journal.Com. Retrieved from: www.self-help-healing-artsjournal.com/artbenefits-brain.html

Eisner, E. (2002). The Arts and the Creation of Mind. New Haven and London: Yale University Press.

Fulbright, H. M. (2003). Teaching Through Art. In: Innovations in Education: The Art and Science Partnership. Doha: The Qatar Foundation for Education, Science, and Community Development. October 19-20, 2003, Qatar, pp. 11-13.

Gotlieb, M. (2002) . The Painter's Secret: Invention and Rivalry from Vassar to Balzac, The Art Bulletin, Vol. 84. P 469.
حسـان، أميـرة محمد مرسـي (ب + . r)، دور الخيـال في إبـداع فن الحفر و الطباعـة في القـرن العشـرين في أوربـا، رسـالة دكتـور اه

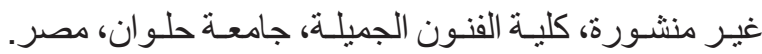
حنفـي، عبلـة (9VY ())، دراسـة الرسـم باعتبـار هوسـيلة تنفسـية، رسـالة ماجستير غير منشـورة، كليـة التربية الفنية، جامعـة حلوان.

خليفـوه، بـدور (10 (Y)، الأنثــة الطلابيـة ودور هــا تجـاه

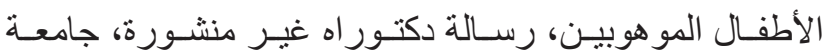
حلـوان، جمهوريـة مصـر العربيـة.

درويـش، كمسال و الحمامسي، محمـ (7 9 (1)، التروبـح و أوقات

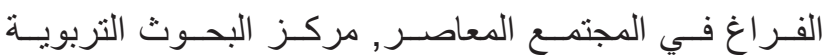

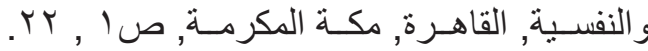

ريــان، فكـري حسـن (990 199)، النشــاط المدرسـي أسسـهـ، أهدافـه، تطبيقاتــه، طـ 0، عالــم الكتـب، القاهـرة.

سـالم، محمـد حسـان (991 (19))، الوظيفـة التربويـة للفن وو اقعهـا الحالـي، مجلـة التربيـة، اللجنـة الوطنيـة القطريـة للتربيـة و الثقافة

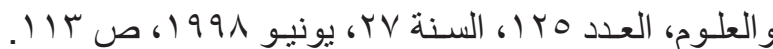
ســالم، محمـد حســان (997 (199)، الفنـون الجميلـة مدخـل إلـى تكويـن الفـرد المتكامـل، المعلـم العربـي، العـدد الأول، دمشـق.

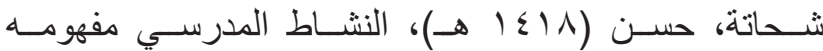

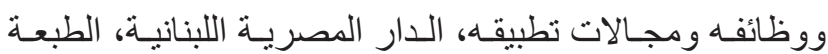

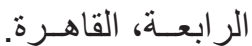
شــحاتة، حسـن (99199)، النشــاط المدرسـي (طب)، القاهـرة: الـدار المصريـة اللبنانيـة. صدقي، سـرية عبـد الـرزاق (9AVV) ( ). البحـث العلمـي في

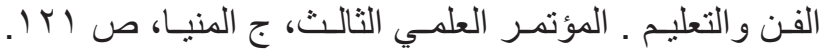
طنـاش، سـلامة (1991) (19)، الأنشــة الطلابيــة فـي الجامعـة الأردنيـة: در اسـة اسـتطلاعية، مجلـة در اسـات الأردنيـة، مجلد

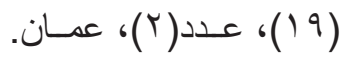
عبـد الحميـد، زايـد (9 ( ) )، الرمـز والأسـطورة الفرعونيـة،

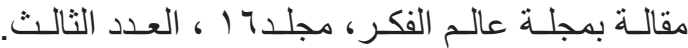
عبـد الرحمـن سـيف إســماعيل (T ( . ب)، نظـرة فـي الفـن

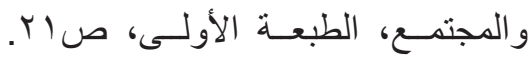


Salem, M. H. (1987) Formation integral par la voie des Beaux-Arts (art Plasitque). These de doctorat. UCL-LIN. 1987.

Thomas, M. Brewer. (2003): Studio Experiences in Art Education, School Arts, Vol. 103, December . P 24.
Guy Hubbard. (2002) . Expressive Faces in Art, Arts \& Activities, Vol. 132, September .P30.

Hope Irvine. (2005). The World's Art in Your Art World, School Arts, Vol. 104, April. P 22.

Huston, A. (2002) . Reforms and Child Development, The Future of Children, Vol. 12, 2002 .P 59.

Katter, E. (2003). What Do The Arts Do Best? In: Innovations in Education: The Art and Science Partnership. Doha: The Qatar Foundation for Education, Science, and Community Development. October 19-20, 2003, Qatar, pp. 37-39

Kernan, C. (2002) Falling for Clay Leaves, Arts \& Activities, Vol. 132, October .P 42.

Lewis, Anne C(1999) What It Means To Be A "Good Citizen" In Australia Perceptions of Teachers, Students And Parents, Theory And Research In Social Education, Vol.27, No. 2, PP.215- 247.

Lowenfeld and Brittain (1987). Creative and mental growth, New York: Macmillan, pp62-67.

Medley, R. (2001) Science and arts: an exciting combination. Teaching PreK-8, 31(5), pp: 46-47.

Michelle, R.(2003):Shoreline Paintings. Arts \& Activities, Vol.133, April. P 56.

Nicholson, J. (2002) Expressing Culture through Art, Arts \& Activities, Vol. 132, December, P 20.

Pamela, G. Taylor, G. , Carpenter. S (2005) Computer Hyper textual "Uncovering" in Art Education, Journal of Educational Multimedia and Hypermedia, Vol. 14, P 25. 